\title{
Entre la teología y la labranza: el clero rural galiciano en los siglos XVI-XIX
}

\author{
Pegerto Saavedra ${ }^{1}$
}

Recibido: 26 de agosto de 2021 / Aceptado: 13 de octubre de 2021

Resumen. La Iglesia gozó en Galicia de un enorme poder, no solo por las rentas que percibía sino por disponer de una densa red parroquial que estructuraba un territorio complejo. Desde Trento, y debido al atractivo que la carrera eclesiástica tenía para las familias rurales, aumentó el número de clérigos y su diversidad interna, pues en el siglo XVIII poco más de un tercio ejercía la cura de almas. Los obispos encontraron grandes dificultades para reformar adecuadamente un clero numeroso, apegado a los valores y comportamientos propios del mundo campesino.

Palabras clave: Iglesia; parroquia; clero secular; reforma católica; curas y campesinos; Galicia; siglos XVI-XIX.

\section{[en] Theology and husbandry: Galician rural clergy in 16th and 17th century}

Abstract. In Galicia, the Church possessed enormous power, not only because of the earnings they obtained, but also because they maintained a dense parish network that structured a complex territory. Since Trent, and owing to the appealing nature that an ecclesiastical career held for rural families, there was an increase in the number of clergy and their internal diversity, considering that in the eighteenth century scarcely more than a third worked as parish priests. Bishops encountered substantial difficulties to adequately reform the numerous clergy, who were attached to the values and behaviors natural to the peasant world.

Keywords: Church; parish; secular clergy; Catholic Reformation; priests and peasants; Galicia; 17th19 th centuries.

Sumario: 1. Introducción. 2. Una densa y estable red parroquial. 3. Evolución del número de clérigos, reparto territorial y diversidad interna. 4. La reforma o renovación católica: dificultades y límites. 5. Rudos, coléricos y libidinosos. 6. Epílogo: de la adhesión a la política religiosa "ilustrada" a la militancia antiliberal. Bibliografía.

Cómo citar: Saavedra, P. (2021). Entre la teología y la labranza: el clero rural galiciano en los siglos XVI-XIX, en Cuadernos de Historia Moderna 46.2, 441-486.

1 Universidad de Santiago de Compostela. ORCID: https://orcid.org/0000-0002-0827-1396

E-mail: pegerto.saavedra@usc.es 


\section{Introducción}

La decisiva y multiforme influencia del clero parroquial no suscitó en España las investigaciones que sin duda necesita y merece, y se halla en el terreno historiográfico en clara desventaja frente al capitular y al regular, que han sido objeto de numerosos estudios, pese a que su presencia entre los legos y su impacto por la vía de la asistencia religiosa era muy inferior, aun contando la labor de los misioneros. Los monasterios y conventos, cabildos y colegiatas tienen sus propios archivos, lo que facilita los trabajos heurísticos, y a la vez se regían -y rigen- por reglas que uniformaban los comportamientos dentro de las instituciones de cada orden o corporación, mientras los clérigos que residían en las feligresías, con o sin cura de almas, constituían una especie de fronda de parientes pobres difícilmente gobernable, por su número y diversidad interna. A ello se suma el que estos eclesiásticos no han dejado archivos particulares, ni han tenido cronistas que ponderen sus virtudes reales o supuestas. Es más, los regulares y los canónigos miraban con cierto desprecio o condescendencia, no ya a los mercenarios, sino a los mismos párrocos y vicarios, cuya vida les parecía trabajosa, sus ingresos menguados y sus luces breves ${ }^{2}$.

Añádase aún que la situación de los archivos diocesanos es bastante desigual en cuanto al tipo de materiales conservados y a su organización o clasificación, que difiere de unos a otros, como sabemos por el caso de Galicia, que es el ahora interesa. Los pleitos civiles y criminales ventilados ante el provisor ora se conservan ora no, y en caso afirmativo no siempre tienen series propias; algunas visitas pastorales pueden hallarse en los archivos capitulares, e incluso en el Histórico Nacional si los comisarios de la desamortización decidieron en su momento recoger también documentos que nada tenían que ver con los bienes destinados a la venta, como eran los libros de foros o apeos ${ }^{3}$. En fin, los depósitos de las diferentes diócesis custodian series más o menos voluminosas, como las de expedientes de órdenes, de capellanías y patrimonios, las mencionadas visitas con valoraciones de curatos, etc., pero hasta el presente algunos de estos materiales han sido poco frecuentados por los investigadores, y a nivel territorial hay que señalar que Santiago y Lugo cuentan con más trabajos que Mondoñedo, Tui y Ourense. La complejidad que presentan los archivos en cuestión ha sido, probablemente, una de las causas de la escasez de estudios sobre el clero parroquial, a diferencia de lo que sucede en Francia, en donde sus fondos están clasificados con criterios uniformes en todos los archivos departamentales, lo que ha facilitado la elaboración de monografías sobre numerosas diócesis ${ }^{4}$.

Sería injusto, con todo, no recordar las aportaciones pioneras, como en otros ámbitos, de don Antonio Domínguez Ortiz así como algunas investigaciones muy

Vid. al respecto, Morgado, A: "Curas y parroquias en la diócesis de Cádiz (1714-1834)", Obradoiro de Historia Moderna, 22 (2013), pp. 207-230 (la conclusión, en las páginas 229-230, figura bajo la rúbrica "condenados al olvido"). También Candau Chacón, M. L.: "El clero secular y la historiografía. Tendencias, fuentes y estudios referidos a la modernidad", Revista de Historiografia, 2 (2005), pp. 75-89; Cortés Peña, A. L. y López Guadalupe Muñoz, M. L. (eds.): La Iglesia española en la Edad Moderna: balance y perspectivas, Madrid, Abada, 2007, y Barrio Gozalo, M., "El clero en la España del siglo XVIII. Balance historiográfico y perspectivas", Cuadernos de Estudios del Siglo XVIII, 22 (2017), pp. 51-79.

3 Así ocurre, por ejemplo, con fondos de las diócesis de Mondoñedo conservados en la sección del Clero del Archivo Histórico Nacional (el sistema de clasificación no diferencia entre los libros y legajos procedentes del archivo capitular y diocesano).

4 De varias monografías da noticia Brumont, F.: "La clergé diocésain dans la France Moderne", Obradoiro de Historia Moderna, 22 (2013), pp. 231-248. 
importantes realizadas en las últimas décadas, de la autoría, las principales, de Maximiliano Barrio, María Luisa Candau y Arturo Morgado, y de Baudilio Barreiro las concernientes a Galicia. Por otra parte, las monografías de historia rural dedicadas a diversas comarcas gallegas, impulsadas en su momento por el profesor Antonio Eiras, contienen en las partes dedicadas al estudio de la sociedad páginas de interés sobre la procedencia familiar, el nivel de ingresos, la formación y los comportamientos del clero local. Y es que, además de los archivos eclesiásticos, la documentación fiscal y los protocolos notariales resultan fundamentales para el conocimiento de este grupo social. Al respecto solo hay que lamentar el que hasta el momento se hayan consultado pocos inventarios post mortem de clérigos, sean párrocos o mercenarios ${ }^{5}$.

Y es que la turbamulta clerical residente en las parroquias rurales avanzada la edad moderna es, a la postre, un reflejo del entramado social del que procedía y la vez contribuía a configurar; de ahí la necesidad de abordar su estudio desde perspectivas más amplias que la mera historia eclesiástica: la organización del territorio, los cambios demográficos y agropecuarios, las estructuras familiares y el sistema hereditario, las formas de sociabilidad a nivel de aldea y parroquia, la oferta educativa, el control por determinadas familias e instituciones de los derechos de patronato, son cuestiones que han de tomarse en consideración para entender tanto el acceso a la carrera clerical como el papel económico y cultural de los eclesiásticos en el mundo rural, a menudo el de su procedencia. En este texto trataré de no dejar de lado estos planteamientos poliédricos, a sabiendas de que hay problemas relevantes cuya elucidación competente necesita el apoyo de la antropología, como los referidos a los procesos de aculturación de los jóvenes campesinos que iban ascendiendo por los escalones que conducían al estado sacerdotal y las relaciones que mantenían con sus familias y vecinos una vez que alcanzaran a "decir misa no altar", con independencia de que ocupasen o no un beneficio curado, lo que en principio debería separarles de la comunidad de legos, situándoles en un nivel superior ${ }^{6}$.

La relación de trabajos de los autores citados sería larga, y para evitarla remito al estado de la cuestión de Saavedra, P.: "El clero rural en la España Moderna”, en García González, F., Béaur, G. y Boudjaaba, F. (eds.): $L a$ historia rural en España y Francia (siglos XVI-XIX). Contribuciones para una historia comparada y renovada, Zaragoza, Prensas Universitarias de Zaragoza, 2016, pp. 339-383, y del mismo autor, "Los campesinos y sus curas", en Pérez Álvarez, M. J. y Rubio Pérez, L.: Campo y campesinos en la España Moderna, Madrid, FEHM/ CSIC, 2012, pp. 19-86; vid. también el núm. 22 (2013), de la revista de Obradoiro de Historia Moderna, un monográfico dedicado a curas y parroquias en la península Ibérica, Italia y Francia. Con todo han de mencionarse de forma particularizada dos monografías que de modo sintético abordan el tema del clero parroquial: Morgado García, A.: Ser clérigo en la España del Antiguo Régimen, Cádiz, Universidad de Cádiz, 2000, y Barrio Gozalo, M.: El clero en la España moderna, Córdoba, Cajasur, 2010. De las monografías comarcales merecen citarse las de Barreiro Mallón, B.: La jurisdicción de Xallas en el siglo XVIII. Población, sociedad y economía, Santiago de Compostela, Universidad de Santiago de Compostela, 1973; Pérez García, J. M.: Un modelo de sociedad rural de Antiguo Régimen en la Galicia costera, Santiago de Compostela, Universidad de Santiago de Compostela, 1979; Rodríguez Ferreiro, H.: A xurisdicción do Morrazo, ss. XVII-XVIII, Pontevedra, Deputación Provincial, 2004; Saavedra, P.: Economía, política y sociedad en Galicia. La provincia de Mondoñedo, 1480-1830, Madrid, Xunta de Galicia, 1985, y Fernández Cortizo, C.: La tierra de Montes en el siglo XVIII: estructura demográfica y sistema familiar en una sociedad rural, Tesis doctoral inédita, Facultade de Xeografía e Historia, Universidade de Santiago de Compostela, 2001.

6 Sobre estos problemas resultan de interés los planteamientos de Goody, Jack, en la monografía La domesticación del pensamiento salvaje, Madrid, Akal, 1985 y en la colectánea de la que es editor: Cultura escrita en sociedades tradicionales, Barcelona, Gedisa, 1996. 


\section{Una densa y estable red parroquial}

La Iglesia era, sin duda, en Galicia el estamento más poderoso por múltiples razones: porque percibía, como mínimo, dos tercios del total de cargas satisfechas por los campesinos en forma de diezmos, rentas de foros y arriendos, voto de Santiago, primicia y derechos señoriales, sin computar las partidas casuales, obvenciones o pie de altar correspondientes a los párrocos y vicarios, y cuya cuantía es a menudo desconocida; porque controlaba el sistema educativo y asistencial, lo que en la España del Antiguo Régimen no constituía una novedad; y -lo que no es asunto menorporque disponía de una tupida red parroquial que cubría todo el territorio, cuando ningún otro poder, fuese el real o los de naturaleza señorial, fue capaz de crear en la edad moderna infraestructura institucional y personal parecida a la que estaba a disposición del ordinario eclesiástico en su respectiva diócesis?

$\mathrm{Y}$ esta red o malla parroquial resultaba fundamental en un territorio que ofrecía serias resistencias al control de los diversos poderes: un hábitat pulverizado en unos 30.000 núcleos, en general de pequeño tamaño (salvo en ciertas comarcas de Ourense), unas comunicaciones difíciles, una baja proporción de tierra cultivada, con lo que las aldeas y lugares estaban como escondidos o "sembrados" entre los montes; una lengua oral diferente a la usada en la administración y en general en la escritura, lo que favorecía formas de resistencia basadas en la supuesta ignorancia y en la falta de colaboración; una sociabilidad de aldea y parroquia muy vigorosa y que funcionaba al margen del mundo oficial... Estas barreras se alzaban ante los agentes de los diferentes poderes, en particular del real: la "constitución" de Galicia es muy diferente de la de los otros reinos de la corona de Castilla, repiten a menudo con desaliento los subdelegados que se enfrentaron a la ingente tarea de realizar el catastro de Ensenada.

Pero la Iglesia consiguió, en principio, superar esas difíciles barreras con la institución parroquial, que encuadraba a todos los fieles sin distinción de sexo o estatus, y que como territorio y grupo humano no dejó de fortalecerse desde Trento, de ahí su creciente visibilidad en las fuentes documentales, incluidas las generadas por la administración de la monarquía (catastro de Ensenada, censo de Floridablanca), en las que las aldeas están a menudo ausentes. Hasta los oficiales encargados del catastro de Ensenada lo apreciaron con claridad, caso del comisario García Serón, quien hallaba dificultades para medir las distancias entre las parcelas y los núcleos de hábitat: "respecto esta tierra es diversa de las Castillas u otros reinos, en que los lugares están formados y en unida población", separados unos de otros por dilatados términos,

“acá son cortos y bien conocidos los términos de cada feligresía, cuyas casas componen una dispersa población, aunque estén distantes unas de otras, y son como cortijos y alquerías, que aquí llaman lugares, $[y]$ son las mismas que dan nombre y vecindario a la propia feligresía y forman su esparramada consistencia, sin haber población y parte principal a que poder adscribir la distancia, porque cualquier casa y sus contiguas tierras son parte de aquel todo que se denomina feligresía"».

Sobre la división del territorio por los diversos poderes, Saavedra, P.: Demarcacións, topónimos, papeis, memoria. Sobre a división e control do territorio na Galicia moderna, A Coruña, Real Academia Galega, 2013.

Archivo General de Simancas (AGS), Dirección General de Rentas, $1^{\mathrm{a}} \mathrm{R}$, leg. 1.874. 
A fines del siglo XVIII Galicia contaba con unas 3.700 parroquias, de las que 3.550 eran puramente rurales y 134 correspondían a ciudades y villas, aunque muchas de éstas tenían más de aldeas que de núcleos urbanos. En la década de 1580, según el censo de los obispos, el número de parroquias ascendía a 3.571, con lo que en los dos siglos siguientes el aumento fue solo del 2,8 por cien, pese a que la población se duplicó con largueza. En el nomenclátor de 1900 figuran 3.769, un 5,5 por cien más que en el reinado de Felipe II $^{9}$.

La extraordinaria rigidez de la estructura parroquial, apenas sensible a los grandes cambios demográficos, políticos, económicos y culturales, dio origen a situaciones distintas según las diócesis, como se advierte en los datos de mediados del XVIII.

Cuadro 1. Extensión y habitantes por parroquia en las cinco diócesis de Galicia a mediados del siglo XVIII

\begin{tabular}{lccc}
\hline \multicolumn{1}{c}{ Diócesis } & Número de parroquias & Km2/parroquia & Habitantes/Parroquia \\
\hline Lugo & 1.131 & 6,4 & 194 \\
Santiago & 1.038 & 8,25 & 397 \\
Ourense & 679 & 7,8 & 340 \\
Mondoñedo & 370 & $12,-$ & 422 \\
Tui & 248 & $7,-$ & 800 \\
Total & 3.466 & 7,8 & 353 \\
Galicia* & c. 3.670 & $8,-$ & 354,5 \\
\hline
\end{tabular}

* Incluyendo las parroquias del reino de Galicia que pertenecían a las diócesis de Oviedo, Astorga y León, y excluidas a la vez las de León que pertenecían a Lugo y Santiago.

Fuente: Biblioteca de la Real Academia de la Historia, Censo de Aranda y ms. 9-5467 de Miguel Bañuelos, y las contribuciones de Barreiro Mallón, Baudilio, y Rey Castelao, Ofelia a los vols. 14 y 15 de la Historia de las diócesis españolas.

Las diferencias en punto al número de personas por feligresía son evidentes y acusadas, dado que las cifras de la diócesis de Tui son cuatro veces superiores a las correspondientes a la de Lugo, después de que desde fines del XVI las tierras miñotas hubiesen experimentado un espectacular crecimiento demográfico, frente al estancamiento de muchas comarcas del interior. Pero la red parroquial permaneció extrañamente insensible a coyunturas tan contrastadas, con la excepción de algunos pequeños cambios que tuvieron lugar en Tui en tránsito del siglo XVIII al XIX.

Las desigualdades en lo que toca a la extensión media de las parroquias eran inferiores a las referidas a la población, pues salvo en Mondoñedo, una diócesis con una

$9 \quad$ No es mi intención realizar ahora una historia de la parroquia, sino describir la red existente en los siglos XVIXIX; como obras de referencia pueden consultarse Fariña Jamardo, X.: A parroquia rural en Galicia, Santiago de Compostela, EGAP, 1996; González Reboredo, X. M.: Os santos titulares de parroquias en Galiza, Santiago de Compostela, Sotelo Blanco, 2012; Lisón Tolosana, C.: Antropología cultural de Galicia, Madrid, Siglo XXI, 1971, y la obra coordinada por García Pazos, F.: A parroquia en Galicia. Pasado, presente e futuro, Santiago de Compostela, Xunta de Galicia, 2009. Merece citarse asimismo el gran libro de Le Bras, G.: L'Église et le village, Paris, Flammarion, 1976, en la que insiste en la revitalización de la parroquia, como territorio y grupo humano, después de Trento. 
historia un tanto singular en los siglos X-XIII, los valores oscilan de 6,4 a $8,25 \mathrm{~km}^{2}$, siendo Lugo la que tiene las circunscripciones más pequeñas. Con todo, el mapa adjunto permite observar diversidades internas en cada obispado, y así en el lucense hay arciprestazgos en los que la superficie media de las feligresías ronda los $4 \mathrm{~km}^{2}$. Pero a la postre, lo que predomina en el reino es una red densísima de pequeñas parroquias, a cada una de las cuales le correspondían de siete a ocho aldeas, con los valores máximos en la mariña cantábrica, en donde puede haber de 20 a 30 entidades de población por feligresía, mientras la media de Ourense se situaba en cuatro en $1990^{10}$.

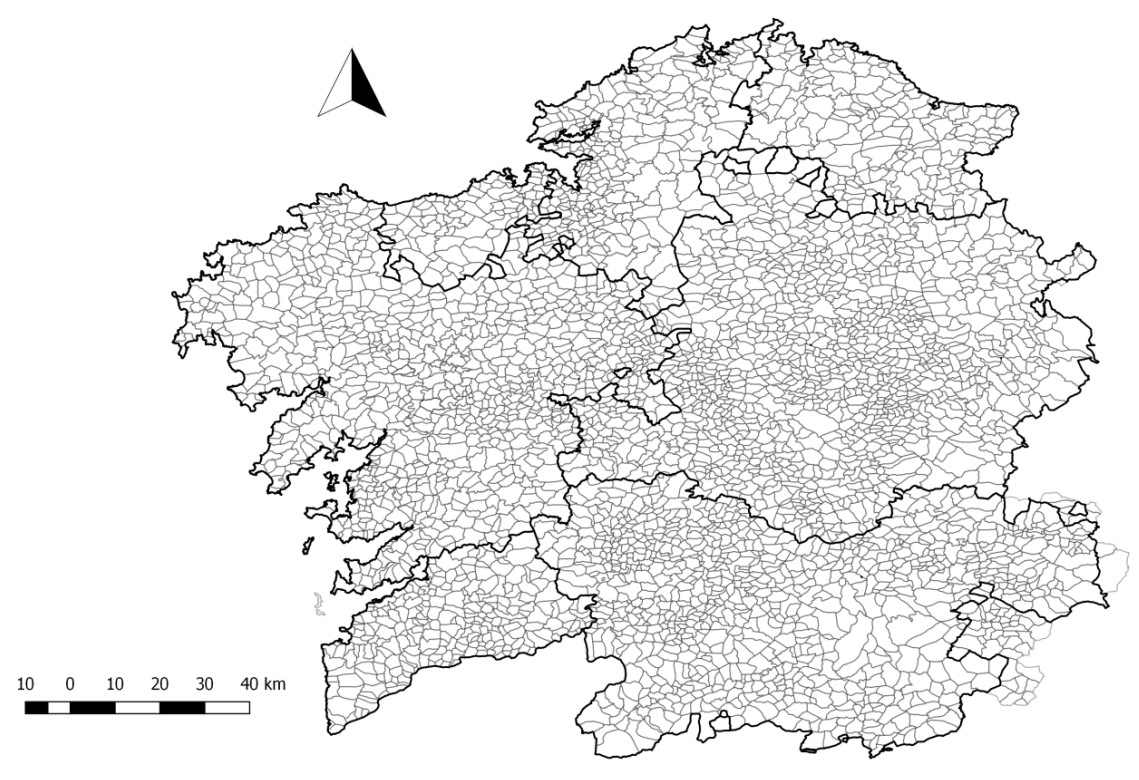

Mapa 1. La red parroquial de Galicia cartografiada sobre la división provincial anterior a 1833 (Elaboración de Anxo Rodríguez Lemos).

No hay lugar ahora para exponer con detenimiento las razones de la estabilidad de la estructura parroquial, que en el mundo rural apenas ha cambiado desde el siglo XIV a la actualidad. Ni la llamada reforma beneficial posterior al concordato de 1753 ni los "arreglos parroquiales" que urgía el de 1851, ni los proyectos debatidos con posterioridad al Concilio Vaticano II tuvieron impactos de entidad en este terreno, salvo algunos cambios de aldeas que en la segunda mitad del siglo XIX pasaron de pertenecer a una feligresía a hacerlo a otra, una estrategia practicada con éxito por los prelados para impedir supresiones que reducirían el número de beneficios curados, en perjuicio de las opciones de promoción de un clero que después de la revolución liberal continuaba siendo abundante ${ }^{11}$.

10 El encuadramiento parroquial era, por tanto, muy estrecho en Galicia, y en general en el norte peninsular, en donde las numerosas iglesias propias se habían ido convirtiendo en parroquias, y mucho más relajado en el centro y sur. La diócesis de Cádiz, por ejemplo, solo tenía 17 parroquias en el siglo XVIII. Vid. Hermann, C.: "Iglesia y poder: el encuadramiento pastoral en el siglo XVIII", Cuadernos de Investigación Histórica, 6 (1982), pp. 137-149

11 Barreiro Fernández, X. R.: “A reforma parroquial de 1867: a diócese de Santiago de Compostela”, en García Pa- 
Hasta mediados del XX, más que el apego de los vecinos a su feligresía, en cuyo cementerio se hallaban los huesos y cenizas de sus causantes, las reformas se ven obstaculizadas por los derechos de patronato, en manos de familias de la nobleza titulada y de la hidalguía de pazo, de monasterios, cabildos y ocasionalmente de parentelas dilatadas. Y es que los datos estadísticos son contundentes: en las diócesis de Lugo, Mondoñedo y Santiago algo más de la mitad de las parroquias eran de patronado de la nobleza con o sin título; un tercio de monasterios, cabildos, órdenes militares y parentelas, de modo que pocas les quedaban a los ordinarios para proveer libremente por concurso; en la de Tui en cambio la situación era algo más favorable al ordinario, que presentaba un 37 por cien de los beneficios. Como es sabido, los derechos de patronato, reducidos desde la revolución liberal a un simple derecho de presentación, estuvieron en vigor hasta el Concilio Vaticano II, con la novedad de que los que pertenecían a monasterios y conventos desamortizados pasaron al rey, cuya condición de patrono le reconoce el concordato de 1851. Así las divisiones o supresiones afectaban a derechos que se ejercían sobre un territorio demarcado -y el carácter territorial de la parroquia no cesó de afirmarse- y por lo mismo rígido, como lo era en general la organización del espacio en el Antiguo Régimen ${ }^{12}$.

Naturalmente, los derechos de patronato no afectaban sólo a la rigidez de la red de feligresías, sino a la selección de los curas de almas, a su formación y a su labor pastoral, como reiteradamente recuerdan los prelados en las visitas ad limina. Pero lo que ahora interesa destacar a propósito de la estructura parroquial densa y estable es que, en principio, facilitaba el acceso de muchos clérigos a beneficios curados, el contacto con sus feligreses de unos rectores convertidos después de Trento en personajes omnipresentes por la proximidad a su rebaño, y algo parecido puede decirse de patrimonistas y capellanes, aunque apenas tuviesen obligaciones de asistencia religiosa. En principio, esta cercanía debería favorecer el control de los fieles y su catequización, pero no está claro que la realidad fuese exactamente así, y una cosa es el poder económico de la Iglesia, y dentro de ella de los párrocos -una verdadera elite rural- y la disposición de una completa infraestructura administrativa, y otra la influencia cultural de la jerarquía y de los curas sobre la población, como habrá ocasión de comentar más adelante.

\section{Evolución del número de clérigos, reparto territorial y diversidad interna}

En un territorio sin apenas núcleos urbanos y estructurado por una malla de pequeñas parroquias, el estamento eclesiástico era básicamente secular, como acreditan los vecindarios y censos de los siglos XVI y XVIII. En el vecindario de 1591 figuran 3.090 seculares y 1.621 regulares, en $1752,8.532$ y 3.173 por el mismo orden, y en $1787,10.309$ y 2.074 , lo que significa que había en esta fecha más de tres seculares

zos, F. (coord.): A parroquia en Galicia. Pasado, presente e futuro, Santiago de Compostela, Xunta de Galicia, 2009, pp. 126-127.

12 Fernández González, A. F., A fiscalidade eclesiástica en Galicia, 1750-1850, Tese doutoral inédita, Universidade de Santiago de Compostela, Facultade de Ciencias Económicas e Empresariais, 1995, pp. 99-112. También el trabajo del canonista de la curia episcopal lucense, buen conocedor del tema, Garrote Martín, A., El derecho de patronato en la presentación a beneficios eclesiásticos según las leyes canónicas y el derecho particular de España, Lugo, La Voz de la Verdad, 1921. 
por cada regular, la mayor diferencia registrada en las diversas fuentes, debida a que la población monástica y conventual iniciara entonces un ligero retroceso, acentuado por la expulsión de los jesuitas, sin que el número de vocaciones de curas notase a esa altura crisis alguna, a juzgar por los expedientes de órdenes ${ }^{13}$.

¿Había en Galicia muchos clérigos? No en términos relativos, pues en 1591 representaban el 0,45 por cien de la población, en 1750 el 0,66 y en 1787 el 0,74, cuando en esta fecha la media de toda España se situaba en el 1,2. Lo que está claro es que el número de seculares aumentó notablemente más que la población total, al multiplicarse por 3,3 en los dos siglos que van de 1591 a 1787, periodo en el que los habitantes apenas se duplicaron. Por tanto caben pocas dudas del atractivo que la carrera eclesiástica ofrecía a diversos sectores sociales, desde las elites a los campesinos, pero conviene analizar la distribución territorial y la diversidad interna de los ordenados in sacris, para ver los contextos familiares y sociales en los que brotaban con mayor facilidad tantas vocaciones, pues en algunas comarcas parece que buena parte de los jóvenes querían llegar a presbítero.

Si reparamos en el marco provincial a partir de los datos de mediados del siglo XVIII, procedentes del catastro de Ensenada, podemos advertir de modo fiable y completo las acusadas diferencias que se advierten en la distribución territorial del clero entre valores máximos y mínimos, que se sitúan, respectivamente, en Lugo y en Coruña-Betanzos.

Cuadro 2. Indicadores de la densidad de clérigos seculares a mediados del XVIII

\begin{tabular}{lccc}
\hline \multicolumn{1}{c}{ Provincia } & \% población & Habitantes/clérigo & Vecinos/clérigo \\
\hline A Coruña & 0,53 & 188 & 42 \\
Betanzos & 0,86 & 117 & 22 \\
Lugo & 0,7 & 149 & 35 \\
Mondoñedo & 0,66 & 152 & 39 \\
Ourense & 0,62 & 167 & 38 \\
Santiago & 0,62 & 160,5 & 40 \\
Tui & 0,66 & 152 & 35 \\
Galicia & & & \\
\hline
\end{tabular}

Fuente: Para el número de eclesiásticos, el llamado vecindario de Ensenada; para el de habitantes el censo de Ensenada, sobre el que calculamos también el número de vecinos, teniendo en cuenta la media de habitantes por hogar, de 5,5 en Lugo y apenas 4 en Ourense, por ejemplo. Los "vecinos" que figuran en la primera fuente no son tales

Las cifras del mundo urbano pesan poco a la hora de analizar las diferentes variables, de modo que apenas afectan a las medias, y en todo caso, la provincia de Lugo, que entonces casi coincidía con la diócesis del mismo nombre, era la más ruralizada y al tiempo la que presenta el mayor número de clérigos por habitante y vecino: uno por cada 22 familias, casi el doble que A Coruña-Betanzos y Tui. Entre el resto de las provincias no hay contrastes tan acusados, lo que obliga a considerar las razones de la singularidad lucense, que parecen hallarse en unas estructuras familiares que también

13 Rey Castelao, O.: “Edad Moderna: Iglesia y religión”, Sémata, 7/8 (1996), pp. 141-161. 
difieren de las del resto de Galicia. En efecto, frente al sistema de herencia preferencial que era habitual en la mayor parte de Galicia, en donde muchos solteros además emigraban, en la provincia y diócesis de Lugo se consolidara a fines del XVII la práctica de la mejora larga, orientada a la transmisión íntegra del patrimonio a un único heredero, a menudo el primogénito. Esto provocaba un elevado celibato masculino y femenino (que no va unido a la emigración) y a la vez favorecía la existencia de un estrato de campesinos medios o acomodados, capaces de sumarse a la abundante hidalguía rural a la hora de fundar una capellanía o de dotar un patrimonio que permitía a algún segundón condenado a la soltería ordenarse sobre esa congrua ${ }^{14}$. La situación tiene ciertos parecidos con la documentada en la Cataluña de los masos hasta mediados del XVIII, bien estudiada por Llorenç Ferrer y por Josep M. Marqués, quienes pusieron de manifiesto la función que cumplían los beneficios personados a la hora de favorecer la entrada de algún hermano del heredero en el clero secular ${ }^{15}$.

Y es que el acceso a las órdenes mayores no dependía tanto del número de parroquias, aunque hubiese muchas, como del ansia de promoción social de numerosas familias campesinas dispuestas a hacer un esfuerzo considerable para proporcionar a algún joven, por vía de patrimonio o de capellanía, la congrua sustentación que sustituía el beneficio parroquial, cuando este no estaba garantizado, cosa que pocas veces sucedía. En la diócesis de Lugo, que contaba con la red más densa de feligresías, los curas de almas representaban en 1768 sólo el 30 por cien de los seculares, en la de Santiago el 45,5 y en Tui el 17, debido a que en este obispado la parroquias tenían en términos demográficos un tamaño muy superior al de Lugo y pocos clérigos podían aspirar a regirlas ${ }^{16}$.

La diversa situación que ocupan los ordenados in sacris dentro del sistema beneficial resulta al respecto elocuente en las fuentes, aunque no siempre utilicen la misma terminología. A nivel general, el censo de Floridablanca relaciona para toda Galicia 2.640 curas de almas y 1.126 tenientes de cura, 2.197 beneficiados, 3.175 ordenados a título de patrimonio y 1.171 ordenados de menores. Por lógica, los capellanes deben de ir incluidos en la rúbrica de beneficiados, pero en todo caso, párrocos y tenientes no suponen más del 36,5 por cien del total de ordenados in sacris, y casi hay tantos patrimonistas como curas de almas, a pesar del mencionado número

14 Aspecto ya destacado por Rey Castelao, op. cit. (nota 13), pp. 170-174; sobre las estructuras familiares y el sistema hereditario, Dubert, I.: Historia de la familia en Galicia en la Edad Moderna, 1550-1850, Sada (A Coruña), Ediciós do Castro, 1992; Saavedra, P.: La vida cotidiana en la Galicia del Antiguo Régimen, Barcelona, Crítica, 1994, y Sobrado, H.: Las tierras de Lugo en la Edad Moderna, Economía campesina, familia y herencia, 15501860, A Coruña, Fundación Pedro Barrié de la Maza, 2001.

15 Ferrer i Alos, L.: "Acceso y distribución de los medios de producción. Herencia y reproducción social", en Chacón, F. y Bestard, J. (dirs.): Familias: historia de la sociedad española (del final de la Edad Media a nuestros días), Madrid, Cátedra, 2011, pp. 255-324, y Marquès, J. M.: "La Iglesia de Gerona", en Historia de las diócesis españolas. 2 Barcelona, Terrrassa, San Feliu de Llobregat, Gerona, Madrid, BAC, 2006, pp. 461-683.

16 La prueba de la escasa relación entre parroquias y clérigos la tenemos sobre todo en el centro y sur peninsular, pues en diócesis como Sevilla el 90 por cien de los seculares eran capellanes, y algo parecido sucede en Cádiz, con solo 17 parroquias en la década de 1730, pero con más de 2.500 capellanías. Vid. Candau Chacón, M. L.: La carrera eclesiástica en el siglo XVIII: modelos, cauces y formas de promoción en la Sevilla rural, Sevilla, Universidad de Sevilla, 1993, y de la misma autora, El clero rural de Sevilla en el siglo XVIII, Sevilla, Caja Rural de Sevilla, 1994; y Morgado García, A.: El clero gaditano a fines del Antiguo Régimen: estudio de las órdenes sacerdotales, 1700-1834, Cádiz, Fundación Municipal de Cultura, 1989, y La diócesis de Cádiz de Trento a la desamortización, Cádiz, Universidad de Cádiz, 2008. También Barrio Gozalo, M.: "Muchos clérigos y pocos curas. El acceso a la clerecía y a los beneficios menores en la España Moderna", Cuadernos de Investigación Histórica, 25 (2008), pp. 293-311. 
cuantioso de parroquias. Dicho de otra forma, los mercenarios sumaban 5.373 y los curas y tenientes $3.766^{17}$.

En la segunda mitad del siglo XVIII el peso desigual de capellanes y patrimonistas dentro de los mercenarios deriva de diferencias territoriales en las estructuras familiares y en las práctica hereditarias, pues a la postre las vocaciones respondían más a decisiones del grupo doméstico, o de algún pariente autorizado, que a la voluntad individual, y el "mercado de beneficios" condicionaba el número de ordenados. El cura Juan Antonio Posse, por ejemplo, refiere como su tío, párroco de la feligresía leonesa de Mañuecas, resolvió por propia cuenta lo que debía estudiar y ser: "Por lo demás, mi tío no tomó otros informes, ni en lo tocante a mi inclinación, ni en orden a los libros: yo debía estudiar Teología y ser eclesiástico", como aconteción ${ }^{18}$.

En la etapa final de Antiguo Régimen había más patrimonistas que capellanes, pero estos predominaban en las comarcas de herencia indivisa y de grupo doméstico de tipo troncal. Así, en la provincia de Mondoñedo el censo de seculares, sin contar los minoristas, se componía en 1752 de 129 párrocos, 47 excusadores, 13 beneficiados, 204 patrimonistas y 81 capellanes. Pero dentro de esta circunscripción, en las cinco feligresías de la tierra de Miranda, con un sistema hereditario articulado en torno a la mejora larga, los curas y tenientes son en 1787 ocho, los capellanes 17 y los patrimonistas tres, al revés de lo que sucede en las circunscripciones de herencia preferencial, en las que los capellanes son siempre minoría entre los mercenarios (tres frente a nueve en la jurisdicción de Barreiros; 17 frente a 39 en el corregimiento de Viveiro, y dos frente a 12 en Galdo). Y los datos referidos a la montaña lucense, tierra por excelencia de la familia troncal y la primogenitura, son contundentes: en 1787 en las 18 parroquias del concejo de Navia de Suarna figuran 14 rectores, cinco tenientes de cura, 39 capellanes y un solo patrimonista, y en el de Burón, la situación es parecida: 25 párrocos y 14 tenientes, 55 capellanes, y solo un beneficiado y cuatro patrimonistas $^{19}$.

Con todo, en las comarcas de herencia preferencial los ordenados a título de patrimonio solo comenzaron a superar a los capellanistas y a los que contaban con un beneficio curado a fines del XVII o en la primera mitad del XVIII, cuando el aumento del número de vocaciones hubo de resolverse mediante la dotación de una congrua constituida por una dote otorgada por la familia del futuro clérigo. Para el conjunto del arzobispado de Santiago los datos aportados por Baudilio Barreiro a partir de los registros de órdenes son en este punto muy luminosos:

Cuadro 3. Título a que se ordenan en el siglo XVIII los clérigos de la diócesis de Santiago, en $\%$

\begin{tabular}{lccccc}
\hline \multicolumn{1}{c}{ Título } & $1656-60$ & $1696-1700$ & $1751-52$ & $1790-94$ & $1851-53$ \\
\hline Beneficio curado & 29,1 & 7,3 & 14,5 & 6,3 & 9,2 \\
Capellanía & 26,7 & 41,6 & $35,-$ & 14,4 & 22,4 \\
Patrimonio & 32,2 & $46,-$ & 53,3 & 69,9 & 63,2
\end{tabular}

17 Utilizo los datos globales del censo, estampado en 1788; los del censo de Godoy, de 1797, son más confusos.

18 En Herr, R.: Memorias del cura liberal don Juan Antonio Posse, con su Discurso sobre la Constitución de 1812, Madrid, Siglo XXI, 1984, p. 26.

19 Real Academia de la Historia, datos locales, por jurisdicciones, del censo de Floridablanca. 


\begin{tabular}{llllll} 
Beneficio simple & 9,3 & 3,9 & 4,2 & 8,4 & $5,-$ \\
Otros & 2,4 & 1,1 & 0,8 & 0,8 & 0,2 \\
\hline
\end{tabular}

Fuente: Barreiro Mallón, Baudilio, "El clero de la diócesis de Santiago: estructura y comportamientos, siglos XVI-XIX”, Compostellanum, XXXIII (1988), p. 480

Resulta muy clara y aleccionadora una trayectoria evolutiva caracterizada por el creciente predominio de los patrimonistas, abrumador en la segunda mitad del XVIII y, lo que parece más sorprendente, aún en la década de 1850. Dada la estabilidad ya comentada de los beneficios curados, los numerosos jóvenes aspirantes a clérigos (de 26 ordenados cada año de presbíteros a fines del XVII se pasa a 60-70 en las décadas de 1760-79) debían contar con otra congrua, y al respecto las capellanías fueron la solución para muchos hasta mediados del XVIII, dotadas en el contexto de la religiosidad barroca por la hidalguía rural y urbana en ascenso, por rectores parroquiales, canónigos y también campesinos, a veces en grupo. Pero consolidadas las rentas de las casas hidalgas y generalizada la pequeña explotación campesina, y sometidas las fundaciones a un mayor control del ordinario, que en las visitas pastorales obligaba refundir las que por la escasa dotación inicial o por la mala gestión de los patronos quedaran incongruas, las capellanías van perdiendo peso como vía de entrada en el orden sacerdotal. En la visita ad limina de 1725 el arzobispo compostelano se queja precisamente de que sus antecesores habían dado licencia para la fundación de más de 4.000 capellanías, en muchos casos con declaraciones fraudulentas que hincharan el valor de los bienes a ellas asignados: "Semper declarant bona cappellania esse omnino libera et magni valoris". De resultas, si en 1634 había en la diócesis de Santiago unos 700 curas de almas, y además "otros doscientos clérigos que en la tierra llaman mercenarios, los cuales son muy pobres y tratan de ayudar a la administración a los sacramentos de los rectores", y por lo común "son muy ignorantes", en el censo de Aranda los mercenarios se habían multiplicado por 5, llegando a 1.049, gracias a las capellanías y patrimonios ${ }^{20}$.

La remodelación interna dentro del clero secular en la etapa final en el curso de la edad moderna ha sido oportunamente enfatizada por Baudilio Barreiro. Se consolida en el curso del siglo XVIII, a partir de las vías de acceso a las órdenes mayores, un universo de patrimonistas, muy superior en número a los que ya disponían de un beneficio curado o de una capellanía, lo que traduce el peso creciente del campesinado como medio de extracción de los clérigos, pues incluso en la diócesis de Santiago, que contaba con una red de villas costeras y con las ciudades de Compostela y A Coruña, a fines del XVIII la procedencia territorial de los ordenados eran rural en un 70 por cien de los casos, pero entre los patrimonistas el porcentaje supera el 90, sin llegar al 80 entre los capellanistas. El recurso a este tipo de beneficio o congrua es, por lo mismo, propio de un sector muy nutrido dentro de los eclesiásticos seculares, y que en principio constituye una especie de proletariado clerical, formado por mozos que en muchos casos nunca llegaron a regir una parroquia. El hecho de que entre las órdenes de clérigo de epístola y evangelio y las de presbítero transcurran unos seis o siete años, pues la edad media de los clérigos de misa es de 29-30 años, pone de manifiesto que muchos pasaban largo tiempo esperando un beneficio curado, a veces en vano. El que algún mozo resuelva ordenarse a título de patrimonio después

20 Archivio Segreto Vaticano, Relationes Dioecesium, Santiago, 246A 
de participar sin éxito una docena de concursos de curatos es aleccionador, como también el que en la década de 1820 encontremos arciprestazgos, caso del compostelano de Postmarcos de Abaixo, con 19 párrocos, 24 capellanes y 99 patrimonistas, 5,5 por parroquia ${ }^{21}$.

La información de la que disponemos para la diócesis de Mondoñedo no tiene la continuidad de la referida a Santiago, pero aun así los datos apuntan a un fuerte ascenso del número de ordenados desde mediados del XVII y un predominio creciente de los patrimonistas: de un promedio anual de 21 expedientes de órdenes en 166079, se pasa a 43 en 1710-39, y a 67 en 1762-79 (unos 55 de excluir a los religiosos). En el XIX hay grandes discontinuidades, aunque se advierte un lógico retroceso por comparación a la segunda mitad del XVIII: en 1801-02 se ordenan cada año 38 sacerdotes diocesanos y 8 frailes, mientras que después del Trienio y hasta 1834 la media fue de 22 diocesanos y menos de un fraile por año. Y al igual que en Santiago la vía patrimonial se impuso con claridad como medio de acceso al sacerdocio, de ahí que los mercenarios pasasen de representar el 25 por cien de los seculares en 1635 al 60 en 1752, y que en la década de 1760 los ordenados a título de patrimonio supongan el 70 por cien del total, los de capellanía el 19 y los que cuentan con un beneficio parroquial no lleguen al 9 por cien. Bien es cierto que el curso de la vida permitía a más o menos mercenarios acceder a la rectoría de una feligresía; de ahí que por las mismas fechas los párrocos representen el 43,6 por cien del total de clérigos, los patrimonistas el 34,6 y los capellanes el 12,8, mientras un reducido 7 por cien entraría en la condición de beneficiados ${ }^{22}$.

Por lo que quedó adelantado, en la diócesis de Lugo las capellanías parecen haber representado, al menos parcialmente, la función que en las otras cumplieron los patrimonios, y la dotación tiene lugar sobre todo desde fines del XVII, cuando se generaliza el sistema de heredero único y la familia troncal. Para el caso concreto de los arciprestazgos de los Coutos, Antonio Presedo ha documentado el protagonismo que hidalgos y curas tienen en la fundación de capellanías en los primeros momentos, para dar paso según avanza el XVIII a los labradores, cuyo concepto de casa imita el modelo de la pequeña nobleza territorial. El hecho de que los curas doten esta clase de instituciones se debe más al deseo de reforzar su casa de procedencia, con rentas y prestigio, que a pura devoción: el patronato constituía una honra y ofrecía la posibilidad de situar en el estamento eclesiástico a un vástago ${ }^{23}$. Por lo demás, la trayectoria del número de ordenados es ascendente desde fines del XVII, y en el primer tercio del XIX las cifras de los que reciben el presbiterado están al mismo nivel de las de un siglo antes. En todo caso, lo que acreditan los expedientes, y esto no es privativo de Lugo, aunque en esta diócesis el fenómeno se agudice, es la presencia de candidatos de fuera de la diócesis, pues nada menos que el 36 por cien los que reciben alguna orden, desde la primera tonsura al presbiterado, entre 1685 y 1839

${ }^{21}$ Barreiro Mallón, B.: "El clero de la diócesis de Santiago: estructura y comportamientos, siglos XVI-XIX", Compostellanum, XXXIII (1988), pp. 479-484; las cifras de eclesiásticos de numerosos arciprestazgos compostelanos de la década de 1820 en el Archivo Histórico Diocesano de Santiago, Fondo General, leg. 1186/1.

22 Archivo Histórico Diocesano de Mondoñedo, Índice de patrimonios, y Barreiro Mallón, B.: "La diócesis de Mondoñedo en la Edad Moderna”, en Historia de las diócesis españolas. 15. Iglesias de Lugo, Mondoñedo-Ferrol y Orense, Madrid, BAC, 2002, pp. 287-289.

23 Saavedra, P., Sobrado Correa, H. y Presedo, A.: "La red parroquial y el clero rural en la Galicia de los siglos XVI-XIX: resultados de una investigación en curso"; Obradoiro de Historia Moderna, 22 (2013), pp. 119-128 (epígrafe dedicado a los capellanes lucenses, elaborado por Antonio Presedo) 
son foráneos, lo que no significa que aspirasen a ejercer en las parroquias lucenses por falta de vocaciones, que aquí y en toda Galicia sobraban, sino que concurrían como a una romería o feria franca por la facilidad que, en especial en períodos de sede vacante, encontraban para recibir las órdenes mayores. La prueba está en que los bracarenses, que acuden a rebaños entre 1721 y 1734 , justo durante el pontificado de M. de Santamaría y Salazar, no se detienen en Tui, sino que optan por recorrer unos 170 kilómetros más, como si la diócesis de Lugo estuviera regida por un san Ambrosio y quisiesen que él les impusiese las manos... ${ }^{24}$.

A la postre, lo que refleja la multiplicación de patrimonistas, y en su caso de capellanes, es que muchas familias consideraban la carrera clerical como una vía para solucionar problemas hereditarios y para el ascenso social -con exenciones de todo tipo-, en la que merecía la pena invertir, con independencia de que el hijo clérigo acabase llevando una vida semejante a la de un labrador. Pues lo que está claro es que muchos mercenarios malvivían ocupados en tareas indecentes al estado sacerdotal, en parte porque el control sobre el valor y rentabilidad de la congrua era escaso y los declarantes inflaban la tasación de los patrimonios para favorecer el acceso de un convecino al estamento eclesiástico. $\mathrm{Y}$ así acababan trabajando las tierras y cuidando los ganados por sí mismos, administrando patrimonios hidalgos, negociando con la aparcería ganado, con préstamos usurarios o con el arriendo de sisas... Fuera de esto les quedaba la enseñanza ocasional de las primeras letras y la "granjería del purgatorio", en particular la celebración de misas de mandas testamentarias y la asistencia a funerales. Como decía Torres de Villarroel, el presbítero que no regía una parroquia fácilmente acababa en "desventurado oficial de misas", "arriero de entierros" o "sacerdote mendicante" 25 .

La diversidad interna del clero secular, que no dejó de acentuarse hasta entrado el siglo XIX, impide realizar generalizaciones de tipo económico, social y cultural sobre una fronda en la que había de todo. Hasta después de la revolución liberal no existe una "identidad clerical", porque la extracción social, la formación cultural y la posición dentro del sistema beneficial de los ordenados in sacris era muy diferente, según los casos. De entrada hay que destacar que los rectores parroquiales formaban una verdadera de elite, ya que en la mayoría de los casos pueden conceptuarse de verdaderos notables rurales, como revelan sus ingresos y la composición de sus hogares (con 2,8 criados de promedio, cuando los mercenarios que viven independientes tienen uno) y hasta su frecuente condición de hidalgos en la diócesis de Lugo, en la que algunos padrones realizados para la distinción de estados, como el de 1737, especifican si párrocos y mercenarios son "llanos" o nobles, y a muchos curas de almas los vecinos les reconocen la hidalguía notoria (y también a sus hijos naturales), si bien es cierto que en la antigua provincia lucense la nobleza era muy numerosa, con lo que no siempre iba unida a la riqueza ${ }^{26}$. No resulta contradictorio afirmar que

24 Dubert, I.: "Montagnes, clercs et vocations religieuses dans la Galice intérieure, 1685-1859", en Brunet, S. y Lemaitre, N.: Clergés, communautés et famille des montagnes d'Europe, Paris, Éditions de la Sorbonne, 2005 , pp. 78-79. Referencias a la "manga ancha" a la hora de conferir órdenes por parte de algunos obispos, nuncios o cabildos en períodos de sede vacante en Barrio Gozalo, op. cit. (nota 16), p. 307.

25 Torres de Villaroel, D.: Vida, edición de Dámaso Chicharro, Madrid, Cátedra, 1998, pp. 162-165.

26 Archivo Histórico Provincial de Lugo, padrón de hidalgos de 1737 (ahora en curso de edición digital; a diferencia de otros padrones, este presta bastante atención a la condición hidalga o llana de los clérigos). Sobre los hogares de los eclesiásticos, Dubert, I.: "El clero rural en Galicia a fines del Antiguo Régimen", en Romaní Martínez, M. y Novoa Gómez, M. A.: Homenaje a José García Oro, Santiago de Compostela, Universidade 
en la etapa final del Antiguo Régimen buena parte del clero rural procedía de familias campesinas, y a la vez que, entre los párrocos, los de origen hidalgo eran abundantes, porque las casas nobles gozaban de los derechos de patronato de la mitad de las feligresías, y los mayorazgos podían presentar a un segundón o a un pariente próximo, o a algún candidato con el que mantenían relaciones clientelares. En las parroquias de la montaña lucense de San Martín de Arroxo y Santa María de Vilabol, por ejemplo, la rectoría está prácticamente monopolizada en el siglo XVIII por la casa de Gegunde (o Xegunde), con su solar en la primera feligresía ${ }^{27}$.

La solvencia económica de los curas de almas se basaba ante todo en su elevada participación en el diezmo, del que percibían de promedio en Galicia el 60 por cien del total. Tan solo los vicarios amovibles, designados muchos de ellos por monasterios y cabildos, se hallaban en una situación precaria y habían de contentarse con una modesta congrua, yendo los diezmos a los patronos. No era el caso de los rectores parroquiales, que gozaban de estabilidad en el beneficio curado con independencia de la identidad los presenteros, participaban más o menos en la masa decimal, a la que sumaban los derechos de estola y pie de altar-que también cobraban los vicarios- y en ocasiones el aprovechamiento de los bienes diestrales y la percepción de la primicia si no iba a la fábrica. Por los cómputos que es posible realizar a partir de documentación como las valoraciones contenidas en algunas visitas pastorales y en solicitudes que varios párrocos presentan a comienzos del XIX para la exención del noveno, alrededor del 80 por cien de los ingresos de buena parte de los rectores estaba constituido por los diezmos ${ }^{28}$. Y si se tiene en cuenta que debido a las intensas transformaciones del sistema de cultivos la población y la producción agraria se multiplicaron por dos o tres en buena parte de Galicia desde comienzos del XVII, ha de admitirse que los ingresos de los párrocos lo hicieron en la misma medida, al no variar los límites de las feligresías. Esta es una de las razones por las que los beneficios curados más opulentos se localizan en el siglo XVIII en el sur de Galicia, en la diócesis de Tui y comarcas de Ourense, con parroquias de mucho vecindario y una agricultura rica; los de Lugo, en cambio, figuran entre los que tienen menos ingresos decimales, por la pequeñez de las feligresías, en las que además regía un sistema agropecuario de tipo extensivo. Bien es cierto que a menudo los párrocos de Lugo acumulaban dos o tres feligresías, entre la matriz y los anexos.

En las visitas ad limina figuran indicaciones de tipo cualitativo sobre el valor de los beneficios curados. Así, en la de 1614 correspondiente a Ourense el prelado

de Santiago de Compostela, 2002, pp. 101-118. Muchos mercenarios vivían con su familia de origen, Presedo, Antonio, "«Sacerdotes que por estar en casa de sus parientes no tienen yndividuos familiares»: hogares de eclesiásticos y hogares con eclesiásticos en la diócesis de Lugo a mediados del siglo XVIII”, López Díaz, M. (ed.): Historia y Modernidad. Homenaje al profesor José M. Pérez García, Vigo, Universidade de Vigo, 2009, vol. 2, pp. 207-224.

27 Archivo Diocesano de Lugo, libros sacramentales de las feligresías mencionadas. En la montaña lucense, en donde radican las parroquias mencionadas, es fácil comprobar que los rectores llevan con frecuencia el apellido de mayorazgos locales. Los autores de monografías de historia rural también vinculan los párrocos a las elites de la comarca; vid, por ejemplo, Barreiro Mallón, op. cit. (nota 5), pp. 541-568. De modo específico Presedo Garazo, A.: "O clero secular galego de orixe fidalgo na Época Moderna: unha poderosa elite local”, Compostellanum, LII (2007), pp. 651-669.

28 Saavedra, op. cit. (nota 5), pp. 554-560 y Rodríguez Ferreiro, op. cit. (nota 5), vol. II, pp. 426 y ss. Las solicitudes de exención de noveno contienen a menudo información detallada sobre los capítulos de ingresos de los curas (salvo el pie de altar), aunque probablemente estén infravalorados. En el Archivo Diocesano de Mondoñedo tienen serie propia mientras en el de Lugo aparecen en los mazos de Pleitos Civiles. 
señala que la diócesis tiene unos 600 beneficios, "quorum maior pars sunt pingues et multorum reditum", mientras el obispo de Lugo decía en 1723 que gobernaba unas mil parroquias, "...et quam plurimi parrochi habent duas, alii tres, alii quator et aliquis quinque eclesias" ( $\mathrm{sic}$ ) y que toda la diócesis "montanea est, et sterilis, ideoque paupérrima". Más resolutivos son los datos referidos al valor medio de los diezmos percibidos por los curas en las parroquias de las siete provincias a mediados del XVIII, elaborados por Ofelia Rey Castelao: las cifras más altas se encuentran en Tui, en donde la masa decimal de cada feligresía que cobra el "abad" asciende a 3.543 reales, le sigue Ourense, con 2.395, Santiago con 1.769; en Betanzos, Coruña y Mondoñedo los valores oscilan de 1.000 a 1.500 reales, y en Lugo no pasan de 688 , siendo el promedio de toda Galicia 1.594 reales $^{29}$. Como quedó indicado, las diferencias entre rectores no eran tan acusadas, pues los de Lugo solían ingresar los de la matriz y anexos, pero, aun así, los diezmos de tres feligresías de esta diócesis estaban muy por debajo de los de una de Tui. Por otro lado, ha de reparase en que por su carácter fiscal las cifras mencionadas son interesantes a efectos comparativos entre las diócesis, pero no indican los ingresos reales de los curas, sin duda superiores.

La sólida posición económica de los rectores parroquiales se pone asimismo de manifiesto en el hecho de que figuran como mayores hacendados en 1752 en cerca de un tercio de las feligresías, según ha demostrado Ángel I. Fernández González: nada menos que en 1.096 de 3.822 circunscripciones catastradas es el cura la persona que declara los ingresos más elevados, y si la determinación del mayor hacendado se hiciese con criterios homogéneos, diferenciando entradas brutas y netas, sin conceptuar igual el valor de la producción de una parcela y el de la renta foral o del diezmo, por ejemplo, los curas ocuparían todavía un lugar más destacado, porque sus ingresos básicos corresponden a diezmos y, por tanto, han de reputarse en su casi totalidad de netos ${ }^{30}$.

De lo que no hay duda es de que el empleo de cura de almas era muy solicitado, como se infiere de entrada de la inflación clérigos, del número de participantes en los concursos o del hecho de que hasta los linajudos colegiales de Santiago Alfeo abandonasen su cómoda hospedería para regir una parroquia, según refiere el arzobispo en la visita ad limina de 1605: el centro estaba habitado por 24 teólogos y juristas, "de los cuales se eligen de ordinario colegiales para los beneficios curados"31. Y aún más ilustrativa resulta la correspondencia de algunas casas nobles, entre ellas la de Amarante, con derechos de patronato sobre diversas feligresías: la mayor parte de quienes escriben al conde solicitando un empleo no piden una escribanía o una judicatura trienal, sino un curato, bien sea de entrada bien de ascenso, pues este linaje presentaba beneficios de las diócesis de Lugo y Tui, en donde eran más suculentos, según quedó indicado. Los deseos de promoción estaban por tanto más que justificados, aunque los clérigos los disfracen con argumentos embozados, exponiendo por lo común que se sentían viejos y achacosos y les convenía, por razones de salud, el clima suave de la región miñota y no el áspero de la Terra Chá lucense.

29 Archivio Segreto Vaticano, Relationes Dioecesium, Ourense, 96A y Lugo, 463A, y Rey Castelao, O.: "El reparto social del diezmo en Galicia”, Obradoiro de Historia Moderna, 1 (1992), pp. 148-154; también Fernández González, op. cit. (nota 12), pp. 128-131.

30 Fernández González, A. I.: "Los grupos de poder local en Galicia, 1750-1850, Noticiario de Historia Agraria, 9 (1995), p. 132.

31 Archivio Segreto Vaticano, Relationes Dioecesium, Santiago, 246A. 
En los dominios de la casa de Amarante el cursus de los clérigos solía comenzar en el empleo de capellán-mayordomo de alguna administración, para luego, una vez probada su fidelidad al patrón, ser promovidos a una parroquia de entrada, pudiendo con los años ascender a otra mejor con ocasión de las vacantes. Los capellanes que no eran promocionados no dejaban de sentirse frustrados, como confesaba en 1800 uno residente en el obispado de Tui: pese a que habían quedado libres varios beneficios, por muerte o ascenso de sus titulares,

"no he merecido tener lugar para ninguno de ellos, siendo el único capellán que ha quedado sin pan (...). Solo siento las burlas que muchos hacen de mí, gloriándose de mi desgracia, pero algo hemos de padecer en este mundo (...) No obstante, no desespero de mi dicha, bien que hallándome en los cincuenta y seis años me sucederá lo que a los enfermos pobres, que les dan gallina cuando les ponen la extremaunción..." 32 .

Hasta el hecho de que las casas rectorales fuesen en la etapa final de Antiguo Régimen el blanco preferido de las gavillas de ladrones constituye una prueba de la riqueza acumulada por muchos curas. El sacerdote segoviano Eusebio Thomé de la Ynfanta rigió entre 1792 y 1815 tres parroquias de la diócesis de Ourense de patronato de la casa de Monterrei, a la sazón incorporada a la de Alba, y en las cartas que envía a su familia figuran noticias muy vivas al respecto: en octubre de 1794 comunica a su madre que "aquí han robado al abad de Riós, el día 24 por la noche, 30 ladrones de acaballo, pues era el abad más rico que había en Galicia, pues dicen tenía en dinero dos millones (...), y la abadía la da el duque de Alba y vale 40 mil reales cada año". En abril de 1797 él mismo es atacado en el curato de Escornabois, que valía unos 20.000 reales: "El domingo, lunes y martes de esta semana me asaltaron los ladrones a mi casa, pero gracias a Dios no ha sucedido nada"; estaba prevenido con dos pistolas, y pensaba adquirir dos escopetas y solicita que le envíen de Segovia "la espada grande de montar". Peor suerte corrieron en Ponte Castrelo, un beneficio valorado en 40.00 reales, el abad, su hermano y criados: el asalto tuvo lugar el 17 de octubre del 1797, y el sacerdote "hizo fuego tres horas, y al cabo entraron; el mató cuatro ladrones, y luego que entraron mataron a su hermano, como a un marrano, y al abad le quebraron las piernas y los brazos, y las sangre de su hermano se la hicieron beber a los criados, de modo que es una compasión ver tantos ladrones...". A fines del mismo mes, una gavilla muy nutrida roba al abad de Pena, a una legua de Escornabois, 80.000 reales, "mucha ropa blanca y una mula que valía cuatro mil reales..." 33 .

32 Archivo de la Fundación Ducal de Medinaceli (Sevilla), Amarante, leg. 92, sin foliar, con abundantes cartas, también en el leg. 93, pidiendo un primer curato o la promoción a otro más cómodo.

33 Archivo del marqués de Lozoya (Segovia), sin clasificar; debo el conocimiento de estas cartas a la amabilidad del amigo y compañero, prematuramente fallecido, Ángel García Sanz; el abad de Ponte Castrelo fallecería poco después, de resultas de las heridas, y aunque se trata de un curato muy rico el segoviano dice que no lo pretende, porque "la gente es muy mala". Sobre el bandolerismo, López Morán, B.: El bandolerismo gallego en la primera mitad del siglo XIX, Sada (A Coruña), Ediciós do Castro, 1995. 


\section{La reforma o renovación católica: dificultades y límites}

No es mi propósito realizar ahora una exposición detallada del desarrollo de la reforma católica a partir del Tridentino, con algunas interesantes iniciativas anteriores. No cabe duda de que la vida parroquial se transforma notablemente en el curso de la edad moderna, pero eso no significa que muchos elementos poco ortodoxos de las creencias y prácticas religiosas desapareciesen, en buena medida porque una parte significativa del propio clero participaba en mayor o menor grado de la cultura campesina, viviendo, por así decirlo, en un mundo anfibio, que daba cobijo a un tiempo a la cultura letrada expresada en latín y castellano y a la de tipo oral, que hablaba gallego. Atendiendo a este contexto, solo prestaré alguna atención a las limitaciones o resistencias de varia naturaleza que encontraba la renovación católica.

Aún no han sido estudiadas en profundidad todas la visitas pastorales anteriores al concilio de Trento, pero las analizadas confirman que la falta de residencia de muchos titulares de los beneficios curados, que encargaban a un mercenario rudo y aseglarado la asistencia religiosa, prestada de modo irregular, era una realidad muy extendida, así como la ausencia de reserva eucarística, la inexistencia generalizada de cofradías y la inoperatividad de la fábrica, y el mal estado de los templos, pequeños, sucios, con escaso mobiliario y sin otros libros que los imprescindibles, cuando los había, para la celebración de la liturgia, y aquellos destinados parcialmente a almacenes o a usos aún más indecentes, lo que revela falta de delimitación de los espacios sacro y profano. El reducido número de vecinos de las feligresías no facilitaba ni la calidad material de los templos, ni la dotación adecuada de los curas de almas ni la catequización de unos fieles que vivían en aldeas aisladas, habitadas a menudo por menos de media docena familias ${ }^{34}$.

Ciertamente hubo prelados que en la primera mitad del XVI hicieron esfuerzos para mejorar la formación del clero y regularizar la enseñanza de la doctrina. En la diócesis tudense, en la visita de 1528-1529 se ordena a los feligreses que los domingos y festivos envíen a sus hijos a la iglesia para aprender el pater noster, credo y salve regina, disposición reiterada en 1556 ("y enseñe [el vicario] la doctrina christiana en romance a los feligreses al principio de la misa, y traigan a sus hijos a la doctrina y misa") $)^{35}$. La ignorancia, la falta de residencia y la incontinencia de los curas de almas constituían, por este orden, los principales problemas a resolver por los prelados, como revelan tanto las visitas como los sínodos previos y posteriores al concilio de Trento: "Este clérigo sabe poco, y no tiene ningún libro"; "es hombre que no tiene libros en casa y solo sabe gramática", o no dispone de libros,

$34 \quad$ Las visitas de la diócesis de Santiago han sido cuidadosamente estudiadas por Barreiro Mallón, B.: "La diócesis de Santiago en la época moderna", Historia de las diócesis españolas. 14. Iglesias de Santiago de Compostela y Tuy-Vigo, Madrid, 2002, pp. 177-352; para el caso de Tui, González Lopo, D.: "De bárbaros a devotos: la reforma tridentina en Galicia (1550-1750)", en Religión, herejías y revueltas sociales en Europa y América, Bilbao, Universidad del País Vasco, 2008, pp. 141-171, y para Mondoñedo, García Oro, J.: "La vida religiosa en el Valle de Oro a principios del siglo XVI"; Compostellanum, 24 (1979), pp. 121-172. De cualquier forma, las visitas de Tui y Ourense todavía no se han sido analizadas de modo exhaustivo, en parte por los limitadísimos horarios de los archivos diocesanos, que, por otra parte, no ofrecen materiales digitalizados, al revés de lo que sucede con los archivos de Cataluña.

35 Archivo Histórico Diocesano de Tui, Cajón 13, con las visitas de 1528-1529, 1540-1541, 1556, 1571 y $1588-90$. En 1556 la luminaria del Santísimo está muy extendida así como la existencia de los libros básicos, debido sin duda a que las parroquias de la diócesis de Tui tenían un número de vecinos superior al de otras, como las de Mondoñedo y Santiago. 
"y ansí entiende poco", son anotaciones que figuran en una visita a la diócesis de Ourense de 1566-1569

La corrección parcial de esas deficiencias trataron de hacerla los prelados mediante visitas inquisitivas y sínodos frecuentes antes que a través de la creación de seminarios, cuyo papel en la reforma del clero en las décadas que siguieron al Concilio ha sido, a mi juicio, muy exagerada por la historiografía, pues no faltan los autores que afirman que solo por el decreto del 15 de julio de 1563, acordado en la sesión XXIII, sobre los seminarios merecía la pena celebrar el Tridentino. Entonces los padres conciliares establecieron que hubiese en cada diócesis un colegio para niños de menos 12 años, que supiesen leer y escribir, con preferencia pobres,

y den esperanzas por su buena índole en inclinaciones de que siempre continuarán sirviendo en los ministerios eclesiásticos (...). Y para que con más comodidad se instruyan en la expresada disciplina eclesiástica, recibirán inmediatamente la tonsura, vestirán siempre hábito clerical, aprenderán Gramática, canto, cómputo eclesiásticos y demás buenas letras, y la Sagrada Escritura, los libros eclesiásticos y las homilías de los santos, y las fórmulas de administrar los sacramentos, lo relativo a oír confesiones y lo concerniente a los demás ritos y ceremonias ${ }^{37}$.

Ahora bien, ese tipo de colegios no existió en las diócesis de Galicia -ni en otras muchas españolas- hasta la segunda mitad siglo XVIII, y aun entonces no en todas, y, además, los seminarios de la Ilustración y del XIX, con una amplia mayoría de alumnos externos, no pueden asimilarse a los de 1940-1970, en los que los estudiantes pasaban 12 años internos, sometidos a una rígida disciplina y a una formación escolástica que era la misma para todos. En muchos seminarios franceses los jóvenes permanecían solo unos meses, o como mucho dos o tres años, y en los que creó en la archidiócesis de Milán Carlos Borromeo, modelo de prelado reformista, solo estudiaba una cuarta parte de los futuros sacerdotes, y entre éstos los había que cursaban únicamente la que más adelante se llamó "carrera breve" (muy habitual en los gallegos hasta avanzado el siglo XX), reducida a unas nociones de Filosofía y, dentro de la Teología, a la Moral, necesaria para poder sentarse en el confesonario ${ }^{38}$. Por otra parte, los padres conciliares del Tridentino tampoco aspiraban a contar con curas sabios, sino con pastores que supiesen lo necesario para dar pasto espiritual al rebaño, que residiesen en el beneficio y que llevasen una conducta arreglada que los diferenciase de la comunidad que gobernaban, a la que no debían escandalizar. El Concilio convertía el sacerdocio en una profesión y quienes la abrazaban debían asumir y defender la dignidad de su ministerio que, entre otras cosas, otorgaba poder. Los padres tridentinos eran conscientes, además, de las dificultades que implicaba financiar los colegios previstos y de que estos no bastarían para formar a todos los aspirantes al sacerdocio, pero que las enseñanzas

36 Archivo Histórico Diocesano de Ourense, Visitas a beneficios, 1566-1569. En estos años abundaban los curas de almas que ejercían en la diócesis que nacieran en Portugal.

37 En Corral Martínez, A.: Historia y pedagogía del seminario de Astorga, 1766-1966, Ponferrada, Peñalba Impresión, 1993, p. 530; el acuerdo figura como canon 18 ("De Seminariorum erectione et regime"), dentro del decreto Conciliar "De Reformatione".

38 Vid., la colectánea editada por Sangalli, M.: Pastori, pope, prete, rabbini. La formazione del ministro di culto in Europe (secoli XVI-XIX), Roma, Carocci editore, 2005, y el artículo del mismo autor "La formación del clero católico en la edad moderna. De Roma a Italia, a Europa”, Manuscrits, 25 (2005), pp. 101-128. 
ofertadas por las órdenes antiguas o recientes -los jesuitas- constituían una satisfactoria oferta alternativa ${ }^{39}$.

Pues bien, en Galicia los llamados seminarios de Mondoñedo y Lugo no pasaron de ser, en lo fundamental, hasta la reforma impulsada por Carlos III, escuelas de Gramática para niños pobres que ayudaban en el coro catedralicio. Las constituciones del mindoniense son de 1594, y no dejan lugar a dudas sobre el tipo de enseñanza que se impartía, y el de Lugo estaba construido en 1601, según la visita ad limina de ese año: "Hay en la dicha ciudad erecto un seminario, debajo de la invocación de Sant Lorenzo, está el edificio principal hecho y le van poniendo en perfectión de manera que dentro de muy poco tiempo podrán estar en él los colegiales". En este caso estaba previsto que los cursantes asistiesen a conferencias de dos canónigos de oficio, de modo que pudieron aprender algo más que latín, en cuya enseñanza había gran esmero a juzgar por el programa de mediados del XVIII ${ }^{40}$.

Poco pudieron ayudar por tanto a la reforma del clero mindoniense y lucense sus madrugadores "seminarios", y de hecho la diócesis de Lugo parece la más parsimoniosa a la hora de asumir, tanto por los eclesiásticos como por los legos, la renovación católica tridentina. Había, desde luego, otros centros en los que los aspirantes al sacerdocio podían estudiar, comenzando por los de Santiago, ciudad que disponía de una infraestructura educativa sin parangón en Galicia: la propia Universidad, que naciera como seminario, contaba desde mediados del XVI con las facultades de Artes y Teología, a la que pronto se sumó la de Cánones (y dentro de la Universidad, el colegio de San Jerónimo para estudiantes pobres, cursantes de Artes, venía a ser un seminario); los colegios de franciscanos y dominicos (los de estos restablecidos a mediados del XVII) y el de los jesuitas admitían asimismo alumnos externos, sin vinculación con las órdenes respectivas, y de hecho desde fines del XVII a la década de 1760 atrajeron a muchos jóvenes que dejaron de ir a la Universidad, porque para ser clérigo poco más daba estudiar en un centro que en otro. En las demás ciudades y villas de cierta importancia estaban abiertas escuelas de Gramática y existía algún convento mendicante, cuyos frailes podían enseñar rudimentos de filosofía y de moral, y en Monterrei, Monforte, Ourense, Pontevedra y A Coruña abrió colegios la Compañía. Con todo, en Lugo, Mondoñedo y Tui, cabezas de diócesis, la oferta educativa era muy escasa, comparada con la que existente en Compostela ${ }^{41}$.

Conocemos la red de centros educativos posterior al Tridentino, pero menos la formación concreta de los aspirantes a órdenes. Sin duda era variada, y muchas veces

39 Sobre el tipo ideal de cura de almas tridentino hay abundante publicística; vid. por vía de muestra, Turchini, A.: "La nascita del sacerdocio como profesione", en Prodi, P. (ed.): Disciplina dell'anima, disciplina del corpo, disciplina della società tra medievo ed età moderna, Bolonia, Il Mulino, 1994, pp. 225-256, y sobre los tratados o "espejos" del buen sacerdote, Irigoyen López, A.: "Los tratados de perfección sacerdotal y la construcción de la identidad social del clero en la España del siglo XVII", Hispania, vol. 68, n. 230 (2008), pp. 707-734.

40 Archivio Segreto Vaticano, Relationes Dioecesium, Lugo, 463A.; Fraga Vázquez, G.: El seminario diocesano de Lugo, Lugo, Diputación Provincial, 1989, y sobre el de Mondoñedo, la obra colectiva O Seminario de Mondoñedo, 1565-2013, Centro de formación e de promoción cultural, Lugo, Deputación Provincial, 2015.

41 Sobre la infraestructura educativa, Rivera Vázquez, E.: Galicia y los jesuitas. Sus colegios y enseñanzas en los siglos XVI al XVIII, A Coruña, Fundación Pedro Barrié de la Maza, 1989; Barreiro Fernández, X. R.: A Galicia do Antigo Réxime. O Ensino, a Ilustración e a Política, A Coruña, Hércules de ediciones, 1991 (colec. "Galicia Historia", t. IV); Barreiro, X. R. (coord.): Historia da Universidade de Santiago de Compostela, Santiago de Compostela, Universidade de Santiago de Compostela, 1998, vol. I; Rey Castelao, O.: A Galicia clásica e barroca, Vigo, Galaxia, 1998, y Domínguez García, J. M.: Cátedras de gramática y educación en Galicia, siglos XVI-XVII, A Coruña, Fundación Pedro Barrié de la Maza, 2010. 
informal, adquirida al lado de un pariente cura, capaz de enseñar latín y lo necesario para la administración de los sacramentos. En el trabajo de Baudilio Barreiro sobre los estudiantes de la diócesis de Santiago del siglo XVIII queda de manifiesto la diversidad de situaciones: unos cursan en la Universidad, otros en conventos, otros luchan con la Gramática en alguna escuela municipal y otros asisten a clases con párrocos o incluso mercenarios dedicados a la enseñanza de la Moral, y que cada vez son más abundantes. Existe al respecto una gran flexibilidad, acomodada a un estudiantado de procedencia rural y a la posibilidad que tenían los clérigos de mejorar la formación después de ordenados de presbíteros y hasta de posesionados de un beneficio curado, con vistas a participar en concursos para cambiar de feligresía o incluso para ganar prebendas de colegiatas y cabildos $^{42}$.

Los primeros pasos en la reforma tridentina los anduvieron los prelados recorriendo las parroquias y convocando reuniones sinodales. Las visitas les permitían conocer el comportamiento de los curas de almas, y constatar en muchos casos su patente ignorancia y otros desarreglos, y los sínodos, juntarlos y elaborar constituciones convertidas en textos básicos de los que debían servirse los sacerdotes para aprender las cosas imprescindibles con vistas al correcto ejercicio de su ministerio. Tan precaria era la situación que algunos obispos ordenaron, al parecer con poco éxito, a los asistentes a los sínodos que sacasen copia de las cosas que debían saber y la llevasen para su casa o para la iglesia de modo que pudiesen estudiarlas.

La labor de los obispos de Mondoñedo don Juan de Liermo y don Isidro Caxa de Lara es buena muestra de lo que vengo diciendo. El primero realizó una visita general a la diócesis desde noviembre de 1574 a mayo del año siguiente, y dejó en cada parroquia unos capítulos generales manuscritos, de 51 puntos, orientados a poner remedio a los abusos que advirtiera entre legos y eclesiásticos, en especial a la ignorancia doctrinal de los últimos. Era una solución de urgencia, debido a la imposibilidad de publicar las sinodales que levantaran gran oposición entre el clero. Ante la falta de libros y el desconocimiento del latín por parte de muchos clérigos, la enseñanza personal del propio obispo y los manuscritos con sus mandatos se ofrecían como únicos medios de reforma, aunque de momento con poca eficacia. Don Isidro Caxa de Lara, sucesor de Liermo, sí consiguió, mediante las oportunas negociaciones, aprobar y publicar en 1586 unas decisivas constituciones sinodales, después de que los curas no hubiesen cumplido el compromiso manifestado en el sínodo de 1585 de copiar unos capítulos muy breves:
"para que copiándolas todos los curas, como me lo prometieron, tuviesen alguna luz por donde se pudiesen guiar y regir (...); mas después estuvieron muy olvi- dadizos y descuidados, que todos o casi todos, si no fue tal cual, la dexaron de sacar y se quedaron tan a oscuras como antes, como nos constó en las visitas que después hicimos".

Por eso en el sínodo de mayo de 1586 las amplió y se las leyó a los asistentes durante tres días, y entonces "se remontaron muchas dificultades y se les hacía mal de consentirlas así a humo muerto", por lo que los curas nombraron representantes que a lo largo de cinco días, mañana y tarde, no dejaron de ver "ni un renglón ni de disputar,

42 Barreiro Mallón, B.: "Estudiantes y curas en la diócesis de Santiago en el siglo XVIII", en Estudios en homenaje al profesor Teófanes Egido, Valladolid, Junta de Castilla y León, 2004, vol. 1, pp. 103-130. 
examinar y resolver cualquier duda que se les ofreciese finalmente"43. Nada de la vida religiosa queda fuera del extenso texto de las sinodales, editadas de nuevo en 1618: se ocupan por lo menudo del comportamiento de los clérigos, en particular de los que tienen cura de almas, de los confesores, de las órdenes mayores y menores, de la provisión de los beneficios curados y de las obligaciones de los patronos y también de las parroquias y parroquianos, de la fábrica y las cofradías, y contienen además una completa explicación de la forma de administrar los sacramentos, muy necesaria a la vista de la experiencia de las vistitas pastorales del celoso obispo Caxa de Lara. Sin duda contribuyeron en mayor o menor medida a remediar la ignorancia de los párrocos ${ }^{44}$.

En Santiago los arzobispos don Francisco Blanco y don Juan de Sanclemente, que ocupan la silla en el último cuarto del XVI, conocedores de la ignorancia del clero, redactaron obras básicas, de tipo sintético, apropiadas a las capacidades de hombres rudos y sin apenas letras: la Advertencia de curas y la Summa de Doctrina Christiana, el primero, y pequeños manuales de doctrina, el segundo. Visitaron a conciencia la diócesis, en especial Blanco, quien la recorrió "sin dejar parte por remota y áspera que fuese, sin perdonar a trabajo ni incomodidad suya (...)", lo que le permitió informarse de los pecados públicos, y en particular del comportamiento "de todos los curas, sacerdotes y estudiantes y de su proceder tenía muy individuales noticias y escrito lo particular de cada uno de su buena o mala vida (...) Aborrecía sobre manera el vicio de la deshonestidad y en particular en los sacerdotes y hacía extraordinarias diligencias para medicinar y sanar los mordidos de este alacrán tan venenoso...". Puso grandes esperanzas en los jesuitas, cuyo colegió dotó generosamente en $1577^{45}$.

Por lo que toca a la diócesis de Ourense el prelado decía en la visita ad limina de 1614 que no había sinodales estampadas, pues aunque sus predecesores hicieran sínodos "las constituciones que hacían en ellos las daban en pliegos sueltos, mandando que cada rector las escribiese, lo cual no se hacía ni cumplía". Él reunió a 600 sacerdotes, pero hasta 1622 no salieron de la imprenta las disposiciones de un sínodo, porque la oposición de canónigos y curas, sobre todo en punto a echar a sus hijos de casa, dificultaba su aprobación. Una de las quejas del prelado está precisamente motivada por la incontinencia de los clérigos:

La castidad en este Reyno y obispado en los eclesiásticos se guarda muy mal y aunque se procura hacer el deber en su correctión y castigo no somos poderosos para echarles los hijos de sus casas, aprovechándose de muchos medios que procuran de invenciones, estratagemas y pleitos, y de tenerlos en sus casas resultan el escándalo y mal exemplo que dan a los seculares, y hacerse avarientos, cudiçiosos $\mathrm{y}$ tratantes para dejarlos ricos, y con este color no son nada limosneros ${ }^{46}$.

43 Pérez López, S. y Cantelar Rodríguez, F. (eds.): Sínodos mindonienses dos séculos XVI e XVII, Santiago de Compostela, Xunta de Galicia, 2001.

44 La edición de las constituciones sinodales de Mondoñedo, de 1618, al igual que las conocidas de otras diócesis, pueden consultarse on line en el repositorio Minerva, de la Universidad de Santiago de Compostela.

45 Rey Castelao, O.: "¿Biografía o hagiografía? Memorias Breves del arzobispo Don Francisco Blanco de Salcedo", en Barreiro Mallón, B. y otros (coord..): Cuatro textos. Cuatro contextos. Ensayos de Historia Cultural de Galicia, Santiago de Compostela, Maxin S.L., 2004, p. 76, y Barreiro Mallón, op. cit. (nota 34), p. 219.

46 Archivio Segreto Vaticano, Relationes Dioecesium, Ourense, 96A. Sobre la relajada moral sexual de clérigos y legos en las décadas posteriores a Trento, vid., Contreras, J.: El Santo Oficio de la Inquisición en Galicia (poder, sociedad y cultura), Madrid, Akal, 1982. 
Cuando los mozos accedían a las órdenes con una formación muchas veces elemental y en todo caso heterogénea y sin haber pasado un tiempo en un centro para homogeneizar saberes y conductas, el ordinario y su curia debían llevar a posteriori un control periódico de la vida de los clérigos, mediante las visitas y si acaso a través de la acción judicial, cuando las correcciones fraternas no bastaban. Aquí radica la función central de las visitas, en su vertiente de visitatio hominum y visitatio rerum. Esto es, una verdadera inspección del comportamiento y conocimientos de los eclesiásticos y del estado de la parroquia con su templo ${ }^{47}$. Algunos prelados demasiado rigurosos debieron recapacitar, para evitar motines clericales. Así le ocurrió al arzobispo don Andrés Girón 1670-1680), que se encontró con una resuelta oposición de los rectores de las feligresías, a raíz de los castigos que imponía de resultas de los expedientes abiertos y de la decisión "de implantar exámenes y controles continuados e indefinidos (...), que afectaba incluso a curas ya titulados y consolidados como rectores y sin motivo o causa pública que lo justificase". Los curas celebraron reuniones en los diversos arciprestazgos y otorgaron poderes que firmaron de modo masivo, para forzar al arzobispo a negociar, y al final por mediación del cabildo alcanzaron un acuerdo satisfactorio para ellos, aunque tomaron conciencia de que las reformas, por medios más suaves, acabarían siendo inevitables ${ }^{48}$.

Son justamente las visitas una de las fuentes básicas que permiten acreditar el desigual avance de la renovación católica a lo largo del siglo XVII y primera mitad del XVIII, visible en la residencia de los curas de almas y en la paulatina reducción de los porcentajes de ignorantes e incontinentes, en la creación de cofradías y capellanías, en el funcionamiento regular de la fábrica parroquial, y en la mejora de la arquitectura y mobiliario de los templos. A la vez, las mandas testamentarias y otra variada documentación han permitido a los estudiosos analizar la difusión entre los fieles del mensaje predicado o la llamada por algunos especialistas "segunda conversión del campesinado", merced a la ofensiva catequizadora de los obispos y de sus párrocos, con el apoyo de los regulares a través de las misiones. Aunque considero que el efecto de las misiones, a medio y largo plazo, fue muy limitado, los mensajes transmitidos a los fieles por los capuchinos, dominicos o jesuitas, mediante una estudiada escenografía, son mucho mejor conocidos que el contenido de los sermones de los párrocos, de los que no queda información directa ${ }^{49}$.

47 La bibliografía sobre las visitas es muy abundante; vid. para el caso de una diócesis gallega, Pérez López, S.: "Las visitas pastorales como fuente histórica. Aportación a su estudio en la diócesis de Mondoñedo", Estudios Mindonienses, 3 (1987), pp. 133-165. Desde perspectivas metodológicas, Nubiola, C. y Turchini, A. (ed.): Visite pastorale ed elaborazione dei dati: esperienze e metodi, Bologna, Il Mulino, 1993, y Puigvert, J. (ed.): Les visites pastorals. Del orígens medievals a l'època contemporània, Girona, CCG EDICIONS, 2003, con una amplia bibliografía.

48 Barreiro Mallón, op. cit. (nota 34), pp. 233-234.

49 Los avances de la reforma católica han sido estudiados por diversos investigadores, en especial por Barreiro Mallón, op. cit. (nota 21); op. cit. (nota 34), y "El clero de la diócesis de Santiago a través de las visitas pastorales, visitas ad limina, registros de licencias ministeriales y concursos de curatos", Compostellanum, XXXV (1990), pp. 489-515; González Lopo, D. op. cit. (nota 34), y Los comportamientos religiosos en la Galicia del Barroco, Santiago de Compostela, Xunta de Galicia, 2002; Saavedra, op. cit. (nota 14); Rey Castelao, op. cit. (nota 13). López, Roberto J.: "Las cofradías gallegas en el Antiguo Régimen", en Obradoiro de Historia Moderna. Homenaje al profesor Antonio Eiras Roel en el XXV aniversario de su cátedra, Santiago de Compostela, Universidad de Santiago, 1990, pp. 181-200. Sobre las misiones, Fernández Cortizo, C.: "Les missions populaires dans le Royaume de Galice", en Missions religieuses modernes. Notre lieu est le monde, Rome, École Française de Rome, 2007, pp. 315-340. 
Pero la reforma tridentina fue compatible con la permanencia e incluso intensificación de formas de sociabilidad comunitaria censuradas por la jerarquía eclesiástica -pero toleradas en la práctica por los curas-y con una cultura "popular" de base parroquial en la que no es posible separar lo religioso y lo profano y, a la postre, la parroquia, cuyo vigor no cesa de aumentar desde la segunda mitad del XVI, acabó convertida en mucho más que una institución religiosa. La fortaleza del cristianismo campesino radicaba en su carácter comunitario, coral y utilitario, y no tanto en una instrucción doctrinal rigurosa, que, a juzgar por testimonios de varios sacerdotes de la etapa final del Antiguo Régimen, los curas, con ser tantos y omnipresentes, no habían conseguido hacer llegar a sus fieles. Si la salvación constituía un asunto personal de extrema importancia, los medios para conseguirla dependían de la ayuda del rector y de la propia comunidad vecinal, en la que las normas de reciprocidad regían también para los deberes religiosos. Misas, velatorios, funerales, rogativas, romerías..., no eran acciones individuales sino vecinales, y la participación en ellas no exigía una adecuada formación catequética ni un respeto cotidiano a los mandamientos. Es más, cada vez existen mayores evidencias de que los curas fueron, muy por delante de los misioneros, los principales promotores de la devoción a los diversos santuarios que proliferaron por el reino, ya que para los párrocos constituía una bendición tener en la feligresía un santo que reuniese romeros y limosnas, aunque no todos tenían esa suerte ${ }^{50}$.

Así, el cura Posse recuerda el contexto cultural y moral de la comarca del Finisterrae en que naciera en 1766 :

Unos curas de presentación ignorantes o criados de servicio, clérigos mercenarios, ebriosos y conjuradores y todo un clero cuya sabiduría era un poco de mal latín y algunos casos del padre Larraga, componían todo lo que por las cercanías había de más ilustrado. El país, ciego en la más grosera superstición, siempre en romerías y peregrinaciones muy largas, buscando exorcistas afamados; la lascivia más impúdica en todas las clases y aun desde la más tierna edad...

Su mala opinión del clero regular y secular sale a relucir con frecuencia, también en el Discurso sobre la Constitución de $1812^{51}$. Y el religioso que ejercía la cura de almas en Poio relataba en 1793 los trabajos y hasta conflictos que enfrentara para sacar de la ignorancia doctrinal a los feligreses: "esta gente es sumamente ignorante, y tanto que de algunos ancianos se puede dudar con muchísimo fundamento si por esta razón son capaces de sacramentos (...)". A pesar de los esfuerzos de dos de sus antecesores,

50 Saavedra, op. cit. (nota 14); Dubert, I.: Cultura popular e imaxinario social en Galicia, 1480-1900, Universidade de Santiago de Compostela, 2007, y Dubert, I. y Fernández Cortizo, C.: "Entre el «regocijo» y la «bienaventuranza». Iglesia y sociabilidad campesina en la Galicia del Antiguo Régimen”, Sémata, 6 (1994), pp. $237-261$. Sobre el carácter colectivo de las prácticas religiosas, que conservan por iniciativa de los concejos muchos elementos del folklore agrario, ha insistido a propósito de León Rubio Pérez, L.: "Curas, feligreses y concejos: relaciones, conflictos y consensos en el reino de León durante la edad moderna", Tiempos Modernos, 36 (2018). Del estudio de los santuarios de Galicia se viene ocupando Anxo Rodríguez Lemos, cuya Teis Doctoral, elaborada bajo la dirección de la profesora Ofelia Rey Castelao, está prácticamente concluida.

51 En Herr, op. cit. (nota 18), pp. 20 y 259-60. A Posse le repugna especialmente que los eclesiásticos seculares y regulares sean titulares de señoríos. 
cuando entré a gobernar el curato estaban tan ignorantes que se encontraban muy pocos que supiesen persinarse, el Padre nuestro, Salve, Credo (...). A vista de esto me tomé el trabajo de hacerles aprender estas cosas (...). El modo de hacerlo fue hacerles ir y venir infinitas veces, haciendo a algunos que fuesen a la escuela, y a otros poniéndoselos en la cárcel, aunque como no estaban acostumbrados a estas cosas se encendían y abrasaban de cólera y rencor contra mí, pero al fin conseguí algo de lo que intenté (...).

En fin Santiago Pastoriza Taboada, a la sazón rector de la parroquia de Urdilde, en el arzobispado de Santiago, afirma en una memoria dirigida al rey en 1816, en la que defiende la escolarización obligatoria de niños y niñas de aldea, que al llegar a la feligresía halló en ella "la mayor ignorancia de doctrina cristiana, no solo en muchos padres de familia, sino en casi todos los adultos, capaces muchos por su edad para contraer matrimonio". Y "lleno de angustia y aflicción, trató de cortar de raíz tantos males con el establecimiento de una escuela de primeras letras". Al igual otros curas y demás personas que dotaron escuelas, pensaba ante todo en catequizar a la juventud, lo que no se conseguía solo en la iglesia:

hablen los párrocos, y se les oirá decir con harto dolor que es tanta la ignorancia de la doctrina cristiana en muchas de las aldeas que varios hombres con hijos y nietos están incapaces de sacramentos, y otros fueron llamados para las armas sin que jamás hubiesen cumplido con la Pascua ¿Qué aflicción, pues, mayor para un pobre cura que ver delante de sí unos feligreses venerables por sus canas, pero enteramente despreciables por ignorar hasta lo preciso para salvarse ${ }^{52}$.

Se trata de textos escritos por sacerdotes exigentes y bien formados y que tal vez exageran la ignorancia de la doctrina por parte los fieles, y los juicios tan negativos que Posse formula sobre los curas no han de generalizarse. Pero parece cierto que muchos sacerdotes, por su origen familiar, por su limitada formación intelectual y por un elemental pragmatismo que les llevaba a acomodarse al medio en que habitaban, eran tolerantes y poco exigentes, aunque tuviesen una conciencia clara de la superioridad que les otorgaba la pertenencia al estamento eclesiástico y en el caso de los párrocos la jurisdicción de que estaban investidos. Y los campesinos sin duda preferían rectores con una formación básica y flexibles antes que consumados teólogos que los amonestaban y hasta multaban por cualquier falta y los sometían a una verdadera tortura con los exámenes de doctrina previos al precepto pascual, asunto que daba origen a disgustos y conflictos, como el suscitado en 1751 entre el párroco de San Mamede de Coeses y varios feligreses que no estaban dispuestos a aprender más, pues consideraban que sabían lo necesario para salvarse: uno de ellos le replicó, desentonado, el día señalado para la confesión, "que había de pasar con lo que sabía", lo que no sucedió, por lo que proclamó a grandes voces: “isean testigos que me niegan los sacramentos...!". Otro de los agraviados declara ante el provisor que el cura le tiene ojeriza y le provoca con preguntas sobre "figuras y cuestiones ridículas, que no es capaz de entender, como qué virtudes daba el mundo, qué le tenían (sic) los santos y otras proposiciones muy confusas y nada arregladas a la doctrina del $\mathrm{P}$. Gaspar de Astete", que es la que han explicado los párrocos anteriores y él sabe, "no

52 Archivo Histórico Diocesano de Santiago, Instrucción Pública, leg. 459. 
obstante de no saber leer"53. El correcto aprendizaje de la doctrina parece un problema crónico, y lo reconocía el arzobispo de Santiago en la visita ad limina de 1634: "Hay mucha falta de doctrina cristiana, y quien menos la sabe es la gente anciana", y aunque los rectores por constitución sinodal tienen que enseñarla y no admitir sin ella al precepto, "excúsanse con decir que de preguntarla públicamente se ocasionan pesadumbres y disgustos entre ellos" y pleitos. También menciona las dificultades que entraña la dispersión de la población ${ }^{54}$.

En las visitas ad limina los prelados reiteran, a modo de cantinela, que el estorbo principal para una auténtica reforma del clero radicaba en la extensión de los derechos de patronato, que les ataba las manos a la hora de elegir a los pastores adecuados. Según la relación de 1614 del de Ourense, los patronos presentan a sujetos que solo visitaron la gramática y algunos casos de conciencia "per aliquas sumas (sic) in vulgari scriptas", y después que tomaron posesión no cogen otro libro y olvidan lo poco que saben. El de Tui exponía en 1655 que, en unas pocas parroquias de la orden de San Juan, los estudiantes, "siendo tan incapaces que aún leer no saben, se ordenan por los obispos de anillo con reverendas de los vicarios de la misma orden, que también son clérigos ignorantes", que no saben latín ni casos de moral. Pero el problema afectaba a muchas parroquias del obispado, en las que los presentados, "siendo notoriamente idiotas, y tanto que no saben leer latín, se van al nuncio de Vuestra Santidad y con falsa relación y quexas del ordinario, $(y)$ vuelven ordenados de todas las órdenes sagradas". Según el prelado, los patronos deberían elegir a un candidato ya aprobado en concurso, como ya disponía el Tridentino, norma que en Galicia quedó en letra muerta. El arzobispo de Santiago se quejaba en 1721 que las 1100 parroquias de la diócesis eran de difícil administración debido a la dispersión de la población, a los problemáticos accesos y la escasa dotación, y añadía que "maior beneficiorum pars laicorum est praesentatio, quod quidem multarum est causa litium". Y el obispo lucense realizaba también en 1766 una detallada crítica de los patronatos de legos, cuyos titulares presentaban para los curatos a familiares, a fámulos y a otros individuos sin las calidades necesarias, que contra la voluntad del ordinario acababan aprobados: "et reprobate in examine, coram Episcopo a sinodalibus facto, appellionem ad superiore de riguroso examine interponunt". El prelado que estaba al frente de la diócesis en 1824 continuaba con quejas parecidas: las parroquias eran muchas, "pauciores vero in concursu generali eliguntur, qui quidem potiore instructione et idoneitate reperiuntur”. ¿Por qué el patronato ha de impedir nombrar a los curas más adecuados para instruir a los fieles?, concluye el obispo ${ }^{55}$.

Por su parte, el arzobispo Múzquiz justificaba en 1804y 1807 la necesidad de un seminario diocesano para remediar los males que causaban los derechos de presentación particulares, muy extendidos en la diócesis, y cuyos titulares

por lo común presentan a sus criados, amigos y convecinos, sin más examen de vocación, de suficiencia y probidad que los deseos de hacerles felices por este medio (...). Contentos con las escasas noticias de un poco de Moral, que apenas puede sufragar para ordenarse de presbíteros, y casi vacíos de todas las circunstancias de

\footnotetext{
53 Archivo Histórico Diocesano de Lugo, Pleitos Criminales, mazo 11. Al parecer los feligreses tenían deudas con el cura o con cofradías.

54 Archivio Segreto Vaticano, Relationes Dioecesium, Santiago, 246A.

55 Archivio Segreto Vaticano, Relationes Dioecesium, Ourense, 96A; Tui, 825A; Santiago, 246A y Lugo, $463 \mathrm{~A}$.
} 
instrucción, prudencia, caridad y celo que exige el ministerio parroquial, se constituyen en su parroquia, se miran como superiores de todos los demás, en vez de dirigir a los fieles, instruirles y santificarlos con su doctrina y ejemplo ${ }^{56}$.

Todos estos testimonios deben considerarse con cautela, pues los prelados estaban lógicamente deseosos de acabar con privilegios que limitaban severamente su capacidad de elección de los curas. Sería preciso contar con estudios comparativos sobre la formación y el comportamiento de los curas presentados por la nobleza y los que accedieran a un beneficio por concurso establecido por el ordinario. La correspondencia de los clérigos dependientes de la casa de Amarante y algunos otros testimonios, como el de don Pedro González de Ulloa, abad en varias feligresías de la casa de Monterrei, dejan entrever una actitud obsequiosa hacia el patrono, al que debían "el pan" ("comer el pan de la casa" es frase que emplean los capellanes del conde de Amarante). Pero estos no son más que indicios, y en todo caso conviene recordar que una vez que el elegido se convertía el párroco, el patrono no podía removerle, aunque sí negarle el traslado a otra feligresía mejor.

Más allá del problema de los derechos de presentación estaban las realidades territoriales y socioculturales de un país con el 95 por cien de la población rural y monolingüe, incluida una parte de la hidalguía. Para un joven nacido en una aldea, que de entrada solo conocía el gallego y la comunicación oral, debía constituir una tarea extraña y pesada enfrentarse al estudio del castellano y del latín, antes de abordar todo lo referido a la administración de sacramentos, con el estudio de los casos de moral A alguna de esas dificultades, que implicaba preparar para clérigos a jóvenes vecinos del mundo rural, se refería en 1714 el obispo de Ourense, para argumentar la necesidad de establecer un seminario en una diócesis sin apenas núcleos urbanos: "et domus sunt per montes et valles dispersa unde clerici rudem habent educationem, magis asuescunt ruralibus ocupationibus, quam devotionis exercitiis et litterarum studio". Y las constituciones del estudio de Gramática tudense de 1729 reparaban en el desconocimiento que los alumnos tenían del castellano:

Porque regularmente los mozos de este reino son sumamente bozales, queremos que mientras estudien menores se exorten a que hablen el idioma castellano, y ellos se empeñen en cumplirlo, pues de otra suerte ni entienden lo que se les habla y explica, ni después construyen con limpieza. Y por lo que mira a la cátedra de mayores, queremos que hablen latín (...) Y no lo haciendo así se proceda a un castigo moderado, como palmas, pérdida de puntos, estar de rodillas... ${ }^{57}$.

Es sabido que el padre Sarmiento criticó con dureza el que la gramática se enseñase a los niños a partir del castellano:

"No he leído semejante barbaridad: obligar a los niños a que estudien una lengua muerta cual es la latina por otra que para ellos es más muerta, cual es la castellana, y que olviden la lengua que han mamado, y que les es nativa, cual es la gallega

56 En Barreiro Fernández, X. R: "Edad Contemporánea: los hombres de altar (Aproximación al clero como grupo social", Sémata, 7/8 (1996), p. 187.

57 Maure Rivas, X.: "Estudio de Gramática de Tui: testemuño dunha represión lingüística", A Trabe de Ouro, 27 (1996), pp. 99-109. 
(...) Así todo niño solo por su lengua nativa debe estudiar el latín. Lo demás es necedad" ${ }^{58}$.

Desde luego que los clérigos no olvidaron el gallego, que para muchos constituía su lengua habitual y que les servía para entenderse con sus feligreses. A pesar de la que población era en proporciones muy elevada monolingüe, la jerarquía eclesiástica nunca parece haberse planteado la edición de un catecismo en gallego, pero tampoco hay indicios de que los curas tuvieran dificultades para transmitir el mensaje, lo que hubiera invalidado de raíz su función pastoral. La explicación de esta anomalía se halla sin duda en que la comunicación entre el pastor y su rebaño se realizaba en la lengua que este entendía, sin necesidad de establecer al respecto normas. En el Hospital Real de Santiago las constituciones de 1804 sí obligaban a que los capellanes supiesen la lengua del reino: “...habrá en lo sucesivo siete [capellanes] españoles y dos extranjeros, de los quales el uno posea bien el idioma francés, y el otro el alemán o el inglés, procurando al mismo tiempo que entrambos posean igualmente el español, y en particular el gallego" 59 .

Pudieron encontrar dificultades aquellos curas que eran foráneos, situación a la que se llegaba cuando la nobleza cortesana con derechos de presentación elegía para una parroquia a un extraño al reino, lo que no debió de ser frecuente, pero tampoco insólito. El padre Sarmiento censuraba que hubiese casos de estos: "No sé como toleran los obispos que curas que no son gallegos ni saben la lengua tengan empleo de cura animarum y sobre todo la administración del santo sacramento de la penitencia. ¿Qué es un coloquio entre un penitente rústico gallego y un confesor no gallego sino un entremés de sordos?", y refiere con cierto humor lo que podía ocurrir en el confesionario cuando el sacerdote no entendía el gallego:

El verbo trebellar en gallego, de tripudiare, siempre significa in malam partem y dista cien leguas del honesto verbo traballar o trabajar. Confesor castellano ha habido que hasta después de muchos años estuvo en el error de que lo mismo era el verbo trebellar gallego (fornicar) que el trabajar castellano. Y a los penitentes que decían que habían trebellado tantas veces les decía que en los días festivos solo se podía trebellar una hora, pero en los días sueltos podían trebellar ad laudes et per horas" 60 .

En cartas del segoviano Eusebio Thomé de la Infanta consultadas hasta el presente no he visto referencias a problemas de comunicación con sus feligreses (sí a los deseos de volver a su ciudad), pero quedan epístolas intonsas, cuyo contenido desconozco. Sí se queja de que el obispo obligue a los curas a predicar en los días festivos, una desagradable novedad para él.

58 Sarmiento, fray M.: La educación de la juventud, edición de José Luis Pensado, Santiago de Compostela, Xunta de Galicia, 1984.

59 Constituciones para el régimen y gobierno del Hospital Real de la ciudad de Santiago, y administración, cuenta y razón de sus bienes y rentas, Imprenta Real, Madrid, 1804. Título XII, n. 226 Debo esta información a la amabilidad de mi compañero Roberto J. López.

60 Sarmiento, fray M.: Catálogo de voces y frases de la lengua gallega, edición y estudio de José Luis Pensado, Universidad de Salamanca, 1973, pp. 172-173. Añade el benedictino que el tal confesor no había escuchado la copla popular "O crego e mais a criada/jugaban aos trebelliños/ a criada cai de espaldas/i o cura cai de fuciños...". 
En definitiva, la "constitución" de Galicia no favorecía precisamente la multiplicación de los sacerdotes piadosos y bien formados, alejados de los valores y comportamientos de la rustica progenies. Pero para ser un buen cura de almas tampoco se necesitaba ser sabio y santo. Bastaba con que ofreciera el competente pasto espiritual a sus feligreses, para proporcionarles los medios conducentes a la salvación personal, que no se mostrara avaricioso y que no causara escándalos notorios. Con estas condiciones, los fieles disimularían ciertas faltas, en especial el poco respeto a la jurisdicción del sexto mandamiento. Los estudiosos de la reforma católica parecen a veces como obsesionados por encontrar el momento en el que todos los eclesiásticos manifestaban un comportamiento intachable, olvidando que el justo peca siete veces al día -y los justos siempre fueron pocos- y que, en el contexto de una religiosidad que enfatizaba ante todo la importancia de la buena muerte, no hay nada más humano que dar los huesos a Dios después de haber entregado la carne al mundo. Recordemos al respecto que Juan Antonio Posse, un cura de almas que destacaba por sus estudios y por su rigorismo moral -pues afirma que ni antes ni después de ordenarse tuvo conocimiento de mujer-, consideraba a su tío, fallecido en 1807 , un buen sacerdote, pese a su escaso bagaje intelectual y a que quebrantaba ocasionalmente el voto de castidad:

su vida había sido muy agitada y laboriosa en el ejercicio de la caza (...). Su genio era un poco arrebatado; algo débil en materia de mujeres, pero de un corazón muy noble, amante, caritativo, franco, lo cual le mereció la estimación de sus parroquiales en los tres curatos que había tenido (...). Por lo tocante a su saber no había estudiado sino moral, y esta según el padre Larraga, y más adelante se dedicó a los padres Echarri y Riccis (...). Pero tenía un excelente consejo en los testamentos, enfermedades y exhortaciones a sus feligreses y extraños, y una muy exquisita dirección en el tribunal de la penitencia. Con estas cualidades no podía menos de ser lo que fue, esto es, un excelente cura ${ }^{61}$.

\section{Rudos, coléricos y libidinosos}

Los expedientes judiciales abiertos por los provisores a aquellos clérigos que reincidían en sus faltas, inobedientes a los mandatos de los visitadores y sordos a los consejos caritativos de algún compañero, contienen información detallada que ilustra los problemas comentados a propósito de las dificultades que encontró la reforma tridentina, que aspiraba crear un modelo de cura de almas ejemplar por su respeto a los votos pronunciados antes de acceder a las órdenes mayores y por su conciencia de la dignidad del ministerio sacerdotal, que le obligaba a diferenciarse claramente del rebaño que gobernaba, aunque para darle el competente pasto espiritual debiese estar en contacto con él, viviendo en el siglo.

$\mathrm{Al}$ respecto, la mejor serie de pleitos conservados es la del archivo diocesano de Lugo, que guarda tanto los de tipo civil como criminal, mientras en el de Santiago los expedientes se han perdido en su mayor parte, y en los las otras diócesis la clasificación poco sistemática de ciertos fondos archivísticos impide realizar valoracio-

${ }^{61}$ En Herr, op. cit. (nota 18), pp. 104-105. 
nes, salvo en Mondoñedo, en donde se guarda una serie incompleta de criminales. A partir de la documentación lucense Isidro Dubert publicó hace años un interesante trabajo, en el que clasifica los expedientes criminales ventilados desde fines del XVII a principios del XIX de acuerdo con su temática (aunque los encausados podían serlo por varios delitos), siendo los más abundantes los motivados por malos tratos de palabra y obra, que representan el 28,5 del total, y siguiéndoles los derivados de la incontinencia sexual, que suponen una cuarta parte, correspondiendo el resto a falta de residencia, problemas por el precepto pascual, abusos en la cobranza de derechos y ocupaciones en labores indecentes ${ }^{62}$. Por otro lado, Hortensio Sobrado analizó la tipología de los pleitos entre vecinos y curas conservados en el fondo de la Real Audiencia, y que derivan en un 58 por cien de los casos de problemas por la cobranza de cargas y en un 18 de disputas por servidumbres, aguas y montes, lo que concuerda con la propia naturaleza del tribunal ${ }^{63}$.

Por mi parte he consultado de modo exhaustivo a lo largo de los últimos tiempos una amplia muestra de fondo del provisorato lucense, y a continuación expondré algunos ejemplos que me parecen significativos a la hora de ver las relaciones entre los clérigos, tengan o no cura de almas, y los parroquianos. $\mathrm{Y}$ aunque las situaciones que iremos viendo no deben generalizarse, el hecho de que determinados comportamientos se repitan y se mantengan a lo largo de años constituye una prueba de que no estamos ante eclesiásticos insólitos por su incontinencia o rudeza de costumbres, sino al contrario, ante realidades bastante cotidianas, nacidas del propio origen campesino de los buen parte del clero, que no había abandonado por completo el universo cultural de su familia de procedencia y de la parroquia en la que residía. A la postre el conocimiento del latín y de algo de filosofía y teología era compatible con una existencia propia de labradores, ya se trate de trabajos o de diversiones, con una diferencia importante: los eclesiásticos, y en especial los párrocos, gozaban de un poder que podía abrir la puerta a todo un linaje de abusos, excesos y demasías ${ }^{64}$. Con la finalidad exponer esas realidades, y no con la de recopilar un anecdotario más o menos divertido, he seleccionado los casos que se citan, y que podían alargarse con facilidad.

No resulta infrecuente que un clérigo incurra en varios excesos a la vez, desde la vida aseglarada a la incontinencia. Lo hacía, por ejemplo, el licenciado don Andrés López, mercenario de San Andrés de Paradela, enjuiciado en 1702 por estar amancebado con una casada, a la que ya frecuentara de soltera, y por ocuparse en la labranza: "y asimismo tiene por vicio y costumbre desde el tiempo que es tal sacerdote de cultivar las tierras y regar los prados, segar, majar, carretar los granos de cualquier género que sean, ir al monte con carro y bueis y otro cualquiera labor como si fuera persona seglar", e incluso le enseñó el oficio de labrador a un sobrino, y a conciencia, pues "le daba y tiraba por las orejas interim que aprendía dicho oficio". El mismo año, otro mercenario de San Juan de Laxe fue denunciado por vecinos por problemas de aguas y de marcos y por insultarlos gravemente: a uno le llamó "desvergonzado,

62 Dubert, I.: "Alma de curas y curas de almas. Moral y comportamientos en eclesiásticos en la Galicia interior durante el Antiguo Régimen”, Sémata, 7/8 (1996), pp. 379-411.

63 Sobrado Correa, H.: "Mediadores entre lo humano y lo divino. El clero parroquial como intermediario socio-económico y cultural en la Galicia del Antiguo Régimen”, en López Díaz, M. (ed.): Historia y Modernidad. Estudios en homenaje al profesor José M. Pérez García, Vigo, Universidade de Vigo, 2010, vol. II, pp. $317-335$.

${ }^{64}$ A efectos comparativos remito a Candau Chacón, M. ${ }^{\mathrm{a}}$ L.: Los delitos y las penas en el mundo eclesiástico sevillano del siglo XVIII, Sevilla, Diputación Provincial, 1993. 
negro, hixo de negra y nieto de negra y que su abuela había sido hecha debajo de una higuera (...) y que había de poner las armas de negro en la casa de dicho querellante"; y a otro que no se descubrió ante él le calificó de "pícaro, malinote", y a la mujer de éste de "pícara, mal nacida (...), puerca, sucia, quiénes son tus padres", a lo que la mujer replicó con ironía que "era hija de un canónigo"65. De 1711 es la causa contra don Manuel de Rivas, rector de San Juan de Friolfe, quien embarazó a su manceba, "como también tiene por vicio y costumbre de guardar el ganado en el monte, haciendo borreas en él y sus prados con una hoz en la mano y ayudando a ripar el lino y haciendo otras cosas muy indecentes a su estado y hábito sacerdotal". Y en 1722 el fiscal actuaba contra un mercenario de San Paio de Muradelle que se apropiaba o mataba cerdos, ovejas y cabras de los vecinos, revendía vino y trigo por medidas pequeñas, "y dicho cura, siendo indecente a su estado sacerdotal, fabrica carros y cambas para ellos como también espadelas para espadelar el lino, pasando a venderlas y usando el oficio como si fuese carpintero"; además, había maltratado a unas huérfanas, apropiándose de sus bienes, y embarazado a dos criadas ${ }^{66}$.

En 1719 se enfrentaban en Santa María de Gondrame el párroco y un mercenario que acusaba al primero de molerle a palos, y llegó a interrumpir la misa a gritos: "¡yo pedir perdón a un escomulgado que me mató a palos...!", y a la salida de la iglesia, para enseñar a los concurrentes las heridas que recibiera, "se desnudó en cueros en la calle pública de medio cuerpo arriba y pasó a decir misa dicho día" ${ }^{97}$. Y en la misma fecha el párroco de San Pedro de Santa Comba amenazó al de San Andrés de Castro, que además era arcipreste de los Coutos de Lugo: "diciéndole metía la uña", y que le había de echar del curato, "con la alforja y camisa a cuestas, desafiándole saliese fuera de dicha casa, en donde se verían los dos (...) y con juramentos decía que si saliese dicho Fontela (arcipreste) se había de dentar (sic) los dos, que no era hombre para eso, y que a él tanto se le daba por matar a uno como por matar a un animal". Según un testigo, el párroco de Santa Comba

es persona altiva, descompuesta y mal empalabrada con todo género de personas así eclesiásticas como seculares, jurador y maldiciente, que por muchas y diversas veces los días de fiesta antes de entrar a decir misa a sus feligreses, le ha visto malhumorado, riñendo con su sobrino (...), jurando a Cristo y otros juramentos, y sin haberse reconciliado pasaba a celebrar el Santo Sacrificio de la misa.

De su carácter violento daría prueba el hecho de haber azotado cruelmente al criado de un hermano, después de atarlo con grillos: "que fueran (los azotes) con una grupa, y que cuando se les diera fuera ynterberando (sic, por interpolando) entre ellos, tomando un polvo de tabaco". Al parecer embarazara también a dos o tres mozas, cuyas criaturas se sospecha que fallecieran ${ }^{68}$.

De 1721 es la denuncia de una moza contra el cura de San Juan de Loio, don Pedro Gayoso Ulloa, por preñazgo. El rector quedara sin criada y pidió a los padres

65 Archivo Histórico Diocesano de Lugo, Pleitos Criminales, mazo 2. El expediente contiene otras expresiones del vehemente clérigo, que amenaza con castrar al demandante: "que había de salir capado para el agosto, que tenía coxones (...) y el querellante respondió que también los tenía".

66 Ibidem, mazo 4.

67 También les enseña la espalda a los curas que asisten a una comida y le invitan a sentarse con ellos; ibidem, mazo 3.

68 Ibidem, mazo 3. Una mujer casada dice que no quiso bautizar a una hija suya, y debió ir a otra feligresía. 
de la joven que la mandasen a su casa por un tiempo, hasta que encontrase otra de su satisfacción, y ella obedeció, "aunque fue contra su voluntad". Durante los dos meses que estuvo sirviendo el cura la sedujo:

en cuyo tiempo, con halagos y promesas que le ha ofrecido y de darle estado de casada y la dote correspondiente para ello, la persuadió y solicitó a que con él tuviese trato ilícito de torpeza (...) y en la primera ocasión que la gozó y él cumplió su depravado y pernicioso gusto, la que declara estaba doncella honesta y recoxida.

Cuando se hallaba embarazada de cinco meses, el eclesiástico la envió fuera de la parroquia, "en parte donde no se supiese de tal exceso", con la promesa de asistirla. El padre de la moza afirma que, en efecto, el cura le había pedido que "le hiciese el agasajo de permitir que su hija Dominga López Varela le asistiese en casa para hacerle de comer algunos días ínterim buscase otra criada", y que pronto le comunicó que había tenido con ella

algunos tratos ilícitos, de que resultó hacerse preñada y para que no se supiese de tal exceso y que ella no perdiese su crédito y conveniencias había de perdonarle el arrojo que había tenido con dicha su hija y permitir que la pudiese sacar del lugar y feligresía de Loio, y transportarla a otra parte distante donde no se supiese de su flaqueza, y después que pariese y estuviese buena del parto la volvería a restituir y procuraría darle estado de casada y criaría él a sus expensas la criatura que pariese.

El hombre confiesa que, ante las razones del cura, "quedó exorto (sic) sin saber lo que le sucedía, por no tener otra hija que acomodar sino la susodicha, y $(a)$ esta a muy poca costa la buscaría estado, no sucediéndole el acaso expresado, con ocasión de casar a su hijo mayor en casa y las dotes dentrambos seren a trueque". Pero "habiendo vuelto en sí", se hizo cargo de que "ya que estaba hecho el daño se le había de dar remedio", y aceptó la propuesta del cura, que este no cumplió, pues no buscó marido a la joven, "y por ello ha perdido las conveniencias". El caso es que una vez llevado el niño a la iglesia para acristianarlo no fue devuelto a su madre, sino entregado a un ama de cría y en el momento del pleito, con tres años cumplidos, habitaba en casa de un hermano del cura. Aún después del parto el rector "volvió a tener con ella cópula", y logró "el goçarla dos o tres veces". Varios declarantes atestiguan el carácter violento, con personas y animales, del acusado, quien al parecer embarazara a una o dos criadas más y trataba mal a los feligreses, llamándoles "pícaros", "bribones", "desvergonzados", altercando con ellos a la hora del ofertorio ${ }^{69}$.

Casar a las criadas embarazadas o conseguir que se espontanearan de algún mozo simple constituía una salida para clérigos libidinosos. Catalina López se querelló en 1703 del rector de San Julián de Lobios, por haberla puesto preñada, y el denunciado responsabilizó del asunto a un vecino, que acabó momentáneamente en la cárcel de Monforte, igual que la denunciante. Los testigos de la mujer declaran que estaba en

69 Ibidem, mazo 4. A cada paso insulta a los feligreses llamándoles "pícaros, cabrones, desvergonzados"; el día de una función religiosa agarró a otro cura por el cuello y barba, y este hubo de pedir auxilio; apaleó a un vecino y le llevó una casaca que valía 100 reales, que posteriormente por consejo de un compañero devolvió; golpeó a otro cura, comisario del Santo Oficio... 
opinión de doncella honesta y recogida cuando entrara a servir por cien reales al año, con la posibilidad de cebar un cerdo,

y que le excusaba (al cura) criado, por la sobredicha hacer todas sus labranzas, como era arar y andar carreando con bueyes y carro, y lo mismo que podía hacer un labrador (...). Y después de algunos meses que entrara en su servicio por fuerza y contra su voluntad la había disflorado dentro de su misma casa, de que resultó haberse hecho preñada.

Tuvo conveniencias para casarse, pero corrían rumores de que seguía con el cura, del que al parecer volvía a estar embarazada, según le confesó a la madrina del primer hijo: "quien hiciera el primero hiciera el que estaba en el vientre", o "quen figo un figo o outro". A esta no la casó, tal vez porque optó por atribuir las responsabilidades a terceros, aunque un testigo dice que un convecino le aconsejó que "se casase con dicha Catalina López (...); pues corría fama había parido del dicho cura se lo propusiese y que si le daba una buena dote se casaba con ella, y habiéndolo el testigo propuesto a dicho cura, se alteró". Pero el rector de Lobios había embarazado además a dos hermanas, que sucesivamente le sirvieran; a una la llevó afuera de la feligresía un criado del mismo cura, y a la vista de que iba llorando, la consoló diciéndole "que callase, que si iba preñada iba de un hombre honrado", y a la otra "la casó con un pobre (...), y luego a los pocos días que se casó parió una niña, de que se ha seguido murmuración y escándalo, por haber salido preñada de casa del dicho cura" $"$.

También causaba notorios escándalos don Andrés de Barrio, rector de Santa María de Campos y anejo, amancebado con varias feligresas, y que, según el expediente judicial de 1721, una noche, a deshoras, había dejado un niño recién nacido a la puerta de una casa comarcana, "diciendo recogiesen aquel niño, lo criasen, que era hijo de buenos padres", pero los miembros de la familia persiguieron con perros al inesperado visitante, hasta alcanzarlo, "y volvieron al dicho cura al sitio donde había echado al niño, y se lo volvieron a entregar". Parece que no era la primera vez que hacía algo así, pues de una moza de Aveancos había tenido varios hijos, "y echaron las criaturas a distintas puertas", sospechando los declarantes que pudieron morir sin bautismo. Además, andaba en saraos, fiestas, tabernas y molinos, en ocasiones embozado y con un alfanje, descuidando la predicación de la doctrina, de modo que según una denuncia firmada posiblemente con nombre falso no era pastor sino "lobo carniçero para sus ovejas" 71 .

Es igualmente voluminosa la causa formada en 1727 contra el licenciado don Pedro Valcarce, rector de Santa Baia de Adá. Fabricara por su mano diversas cercas y hasta un molino; maltrataba a los animales de los feligreses y también a estos; de hecho cortara la cola a varias reses de los vecinos y se jactaba de que "les ha de cortar hasta las mismas orejas". Cobraba excesivos derechos y descuidaba la asistencia religiosa, empleando expresiones brutales como cuando se negó a ir a casa de una difunta para acompañar su cadáver y dijo a grandes voces por qué iban a enterrar en la feligresía "aquel puerco muerto, añadiendo después que acaso lo llevarían para salgarlo, todo ello con mucha nota y escándalo"; tuvo igualmente diferencias con el padre de una pár-

\footnotetext{
70 Ibidem, mazo 44

71 Ibidem, mazo 4.
} 
vula fallecida y, como no compareció la tarde del entierro, fue preciso dejar el cadáver de la niña en la iglesia, "encerrado en el arca de los ornatos"

El rector que estaba al frente de Santa María de Vilaragunte en 1730 fue otro de los que dio trabajo al fiscal y al provisor y a algún cura comarcano. Según el expediente de 1731, solicitaba a casadas y solteras a "actos torpes deshonestos" y, después de embarazar a una casada, dio el niño a criar, de modo que los amos "vinieron repetidas veces a casa de dicho cura a cobrar el trabajo de la crianza", satisfecho en centeno y patatas y con la entrega de una vaca, y cuando en una ocasión no les pagó amenazaron con dar cuenta al provisor, porque "estaban hartos de criar hijos de putas casadas y de clérigos"; tuvo además cuatro hijos de mozas solteras, una de ellas criada, a la que habría forzado "atándole las manos". A mayores, los testigos le notan de violento y mal empalabrado, propincuo a insultar a los feligreses con términos como "baboso", "ninguén", "villano", "descamisado", "pidente", "cornudo", "cabrón", y a uno de ellos, a instancias de la manceba que sostenía, lo abofeteó "y cogió contra él un estadullo de un carro y si no concurriesen los vecinos le maltrataba" " Otra presunta violación sale a relucir en un expediente de 1729, cuando Jacinta de Pacios, que servía en una casa de San Pedro de Fornadeiros, denunció en 1729 a un mercenario, del que procreara un hijo después de haberla estuprado o forzado "junto a la seve una bouza" (cierre de una roza), con ocasión de ir a buscarlo por orden de su amo. Y cuando este reprendió al acusado, "respondió dicho presbítero que tuviese paciencia, que ya no tenía remedio" ${ }^{74}$.

Aunque, para violento, el mercenario don Andrés González Valladares, que asistía en casa del cura de San Miguel de Lapio, su tío. Según la abultada causa de octubre de 1754, el día 29 de septiembre, fiesta del patrón de la parroquia, al anochecer, había atacado a un matrimonio a las puertas de su propia casa, con una moderna navaja, con la que hirió y mató a la mujer, al darle una puñalada debajo del pecho izquierdo. Un testigo declara que escuchó voces de auxilio y vio al presbítero con "una navaxa de muelle en las manos, con dos oxas de puntas agudas, la una mayor que la otra; con la que estaba dando de golpes al referido Manuel Fernández y (a) María Díaz, su mujer, dentro de su mesma casa, teniéndoles a entrambos arrimados sin poderse defender". Y la mujer "dijo le valiesen, la que sin pronunciar otra palabra se quedó muerta". Perseguido por algunos vecinos, el clérigo pendenciero se refugió en la casa de su tío, en la que habitaba y donde trató de hacerse fuerte con dos escopetas, "diciendo a los que allí estaban y fueron en su seguimiento «ladrones, villanos, maxaderos, llegaos acá que os he matar a todos»". Al final fue reducido y "asegurado" por los vecinos, hasta que llegó la justicia local para hacerse cargo de él. Al parecer, le gustaba presumir de la navaja poco común que había adquirido, que enseñaba a los vecinos de la feligresía, diciéndoles que era "buena para dar una facada", en lo que, para infortunio de la mujer muerta, no mentía ${ }^{75}$.

Ibidem, mazo 4.

Ibidem, mazo 4.

Ibidem, mazo 5. Según los testigos el clérigo había embarazado a otras dos mujeres, una de ellas viuda, con la que se ajustara por diez fanegas de centeno.

75 Ibidem, mazo 12; el homicida se defiende diciendo que el marido de la difunta, al que amonestara por adúltero, la agredió y él trató de defenderse sin ánimo de herir a nadie, pero no se veía por ser de noche. A fines de 1754 estaba preso en Lugo y en febrero de 1756, con problemas de salud, se le sentencia por homicidio involuntario, pero se le permite salir, debiendo permanecer tres años en la ciudad sirviendo la comida a los pobres del hospital de San Juan de Dios. 
No está claro, en ocasiones, si las quejas de los vecinos obedecen a escándalos morales o si estos son un pretexto para arremeter contra clérigos cuyo comportamiento económico les perjudica. Así, en 1752 fue denunciado el presbítero capellanista don Salvador González, de la feligresía de Santa Eulalia de Pradela, al que atribuían seis hijos de cuatro mujeres, y a pesar de que la renta de su capellanía ascendía a 60 fanegas de centeno, "anda vestido como si fuese un pobre labrador o jornalero". Y no solo se acompañaba de mujeres "transitando con ellas al molino, ferias, mercados y romerías, con mucha nota y escándalo", sino que, cuando en ausencia del rector parroquial, celebraba la misa mayor dominical, "en el ofertorio de ella se pone a modo de predicar, (y) tan lexos está de hacerlo como debía que lo hace de cantar diciendo: «a Castilla van las nenas para ganar, Castilla acá les queda si ellas quiera trabaxar», causando por lo mismo irrisión y malos ejemplos". Añaden que "jamás se le ha visto el breviario en la mano y se presume falta a la obligación del rezo". Probablemente lo que indignaba a los feligreses es que, por su afán aprovecharse de los recursos comunales, andaba "sin la decencia debida su estado, arando y coxiendo leña en los montes", maltrataba de palabra y obra a vecinos, introducía el ganado en tierras que no le pertenecían y cortaba árboles propios y ajenos, "y después los carga y acarrea como si fuese un labrador, y esto aunque sea en los días festivos, y después se va a decir misa", con lo que le queda tiempo para preparar el sermón. A un muchacho que estaba en el monte con el ganado le maltrató, quitándole la montera para mear en ella, pero en general faltaba al respeto a muchas personas, al embriagarse en ferias, romerías, tabernas y funciones de entierros y casamientos, y después decía "palabras lascivas muy feas y descompuestas y (realizaba) otras acciones muy impropias a su estado", con lo que causaba notorio escándalo, así como por no andar "con la limpieza, aliño y aseo que debe como tal sacerdote y cristiano"76.

El maltrato físico por parte de los mercenarios y curas a sus convecinos y feligreses no parece algo excepcional, y puede que en algún caso sea fruto de la simple brutalidad, pero a menudo obedece a la superioridad que los eclesiásticos se atribuían sobre los campesinos. Lo explicaba en 1755 el rector de Martín de Curbián, ante cuya puerta el diácono don Pedro Blanco había golpeado a varios de sus feligreses, que debieron pedir auxilio (" $i$ Ay señor abad, que me mata don Pedro Blanco a su puerta!"): "desde que recibió las órdenes sagradas se ha hecho soberbio y descompuesto, amigo de trabar riñas y pendencias con quien se le antoja, y de andar de noche" 77 . Había, desde luego mercenarios pendencieros, como dos hermanos de Santalla de Pedrafita, que en 1757 agredieron a unos oficiales que estaban serrando unas maderas, casualmente por mandato de otro clérigo: "siendo como son de genio inquieto y revoltoso, amigos de riñas y pendencias, se fueron ellos armados con destrales, que comúnmente llaman machados, muy furibundos y atrividos, amenazándoles de muerte (...) Arrojaron a uno de la estada", rompieron la sierra y trataron mal al clérigo denunciante, "llamándole grande solarmeiro y otras feas e indignas palabras" 78 . Y otro de San Mamede do Carballal, no les iba a la zaga, pues maltrataba a hombres y mujeres, y fue denunciado por un vecino que precisó asistencia de

\footnotetext{
$76 \quad$ Ibidem, mazo 11. Tenía entonces 77 años y afirma que anda mal vestido por falta de medios y que la mujer que tiene en su casa con dos hijos, casada o viuda, la tiene acogida por caridad.

77 Ibidem, mazo 11.

78 Ibidem, mazo 12.
} 
cirujano, y al que había desafiado "diciéndole con votos y reutos le había de partir los miembros, quitar las orejas y hacérselas comer"79.

De los golpes no se libraban las mujeres, de cualquier estado que fuesen: el capellán de un hidalgo de Portomarín maltrató en 1717 a doña Faviana Sarmiento, cuando estaba en una huerta, y después a su hijo, diciendo: "Boto a Christo, pícaro, no se me da por el obispo de Lugo ni por la justicia que ayga, que para mi no hay justicia, y aunque sea a media noche te tengo de moler los güesos" $"{ }^{\prime 0}$. Un mercenario de Santa María de Bolmente golpeó en 1779 a una embarazada, haciéndole malparir:

reconocieron habérsele soltado mucha sangre, corriendo mucha abundancia de él por el tablado del sobrado, en donde se hallaban, despidiéndose y arroxando de su cuerpo un fecto que solo se divisaba la cabeza, por lo redondo, pero no le reconoció tuviese piernas ni brazos ni se conociese fuese hombre o mujer.

El clérigo proclamó arrogante que "no se le daba por el papa, obispo ni provisor" ${ }^{\prime}$. Y en 1783, una viuda de la misma feligresía denunció a otro mercenario que se dedicaba a acopiar herencias de modo fraudulento y que, en una disputa que tuvieran por lindes, "a este tiempo se vino a ella el don Josef, y cogiéndola por la mano derecha la mordió en la izquierda, en la que le hizo dos heridas chicas". Antes ya le había dado de palos al que era marido de la mordida, quebrantando su salud: "con la sotana (de palos) que le había dado el don Josef, iba cada día a menos, por haberle maltrato mucho", dice haberle oído un testigo ${ }^{82}$.

En el caso de los párrocos, la superioridad que se atribuían sobre los feligreses resulta patente: ellos eran los pastores y el rebaño debía obedecerles sumisamente, igual que los niños debían obedecer a sus padres, y en caso contrario merecían ser corregidos con azotes y otros castigos ejemplares, sin más explicaciones, como entendía el cura de San Lorenzo de Pedraza, quien tenía por costumbre golpear a los vecinos, tanto que, según denuncia de 1767, varios precisaron la visita del cirujano, entre ellos uno que iba "arrojando sangre por la cara que parecía un carnero", mientras el rector, después de darle un palo en la cabeza, se marchó tranquilamente a decir misa, "sin saber se hubiese reconciliado" 83 .

La demasiada familiaridad en el trato y la falta de respeto a los curas de almas constituían actitudes merecedoras de severa corrección. El rector de Santa María de Pedraza explicaba el día de San Blas de 1751, al ofertorio de la misa, el catecismo del padre Astete a los fieles, y a propósito del credo, le preguntó a Benito do Campo

qué entendía por el perdón de los pecados y comunión de los santos, y respondió con osadía provocativa y escandalosa, faltando a la cristiana reverencia debida al santo templo y a mi revestido con las sagradas vestiduras deste modo: «dígame también cuántos buratos necesita un carro para ir al monte», con que quedaron todos los oyentes sumamente escandalizados con tan poca obediencia y temor de $\operatorname{Dios}^{84}$.

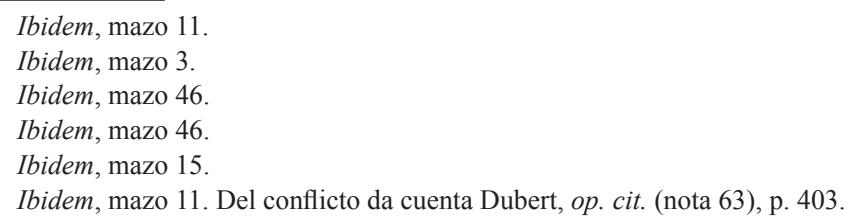


De momento, el rector le multó con dos reales, pero el incidente acabó en el tribunal del provisorato, ante quien Benito do Campo declaró que el cura era persona "de genio ridículo, altivo y dominante", y que en cierta ocasión, cuando le sugiriera que buscase dos hombres para demarcar una parcela del iglesario, "se alteró y colérico replicó que no quería más hombres que su bastón, que con él a palos había de hacer dejar al otorgante la tierra del iglesario"; otro feligrés también sufrió su furia, cuando fue a pagar los diezmos menudos: "cogió un bastón y en él le dio muchos palos y porrazos, en tanto exceso que le partió el brazo izquierdo e hizo otras heridas y mazaduras"; y uno más que se acercó a la rectoral a satisfacer el estipendio de una misa, después de llamar respetuosamente a la puerta, con un "alabado sea el Santísimo Sacramento", encontró al cura riñendo a un vecino, llamándole "«pícaro altivo, que hablar y ese delante de su cura»", y aunque el interpelado replicó: "«señor mi abad, yo en qué ofendí, pues le hablo con cortesía, con la montera debajo del brazo»", no se libró de un fuerte bofetón. A menudo les decía a los feligreses que "les había de hacer buenos a palos". Durante el litigio, algunos vecinos pasan al ataque y acusan al rector de causar escándalo con una criada que ejerce en la propia rectoral el oficio de tejedora: "da mucha nota y ocasiona bastante rumor en el país, mayormente siendo público que el mencionado cura trata a dicha moza con más cariño y estrechez que otra más anciana que le sirve y trajo de su país". A mayor abundamiento, una vez que la nueva criada se aposentó en la casa del cura renovó pronto su vestuario: "la cual antes de entrar en ella andaba en traje muy ordinario, de lana del país, y después mudó al de paño, medias encarnadas, zapato bajo con hebillas, tratando con mucha estrechez y familiaridad al citado don Joseph", al que acompañaba a la feria de Monterroso y en pascua a las diversas casas que visitaba el sacerdote para bendecirlas y recoger de paso los huevos que los feligreses estaban obligados a pagar en la ocasión ${ }^{85}$.

En las parroquias de San Martín de Arroxo y San Esteban de Refoxo corrían igualmente habladurías en la década de 1730 debido a la desenvoltura y afán de lucimiento de la criada del cura, muy ocupado en atenderla:

debiendo, como buen pastor, dar buen ejemplo, no lo hace; antes, en contravención de ello ha vivido y usado mal de su persona antes de ahora, viviendo escandalosamente, y lo hace al presente con una mujer, que su porte es de rodete y vestido correspondiente, con mucha profanidad (...); y del se hizo preñada y parió una niña que bautizó de su orden don Francisco López (...); come con él a la mesa y salen a pasear juntos como a Monforte y romerías, y otras partes, haciendo della toda estimación, causando con ella mucha nota y escándalo; y así ha dicho cura como la susodicha dan de palos a algunas personas, y él no explica la doctrina a los feligreses ni les dice misa en las parroquias ni cumple con las funciones... ${ }^{86}$.

Y el vicario de Amandi se esmeraba asimismo en torno a 1747 en el trato a una criada a la que había facilitado el casamiento, después de que la justicia intentase desterrarla:

85 Ibidem. Aparecen más quejas sobre las dificultades que pone en la doctrina y los testigos afirman, además, que el cura y criada nueva habían golpeado a la vieja, provocándole una herida en la cabeza.

86 Ibidem, mazo 45. Un testigo dice la mujer se cortó el pelo "y su parte en casa es guardapiés de gorgorán y lo más del vestido en correspondencia, y cuando sale, con su dengue encarnado, sombrero y basquiña". 
y sin embargo la volvió a recoger en su casa; y para tratarla con más libertad dispuso el casarla en las cercanías de ella, en donde la comunica diariamente entrando y saliendo con frecuencia en la tal casa (...); y de recién casada la tal mujer, habiendo estado en cama mala de un mal parto que le sobrevino, le fue a asistir dicho acusado y le daba las sustancias por su mano (...), y se corre y murmura que el referido acusado provocaba diariamente a cosas torpes e indecentes a otra cierta mujer casada y otras, causándoles mal vida con sus maridos.

Según declara una tabernera, el sacerdote asistía a la enferma y le daba "las sustancias por su mano, sin quererlas tomar de otro, y el chocolate a las horas que lo pedía", y además había forzado a una cuñada de su manceba, "y que le había puesto un paño en la boca para que no diese voces" $" 87$.

Por su parte, el cura de San Juan do Sixto reconocía en 1776 que, cuando era más joven, daba palos habitualmente a sus feligreses, y que a la sazón, con 70 años, solo castiga a criados y criadas que se desmandan, aunque, según los testigos, el mismo se dejaba maltratar de modo indecente: "oyó por de público que la criada que mantiene en su servicio de cura (...), en una ocasión y poco tiempo ha, cogió a aquel por los cabellos y le echó en el suelo, y aun le arrastró por él, sin mirar al respecto de amo y carácter sacerdotal, procedido de dejarse dominar y floxedad que le asiste", tratándole además con palabras indecorosas, como “judío, villano, mal clérigo”. En este caso, el provisor comprueba que la habitación en la que cura y criada tienen sus camas es reducida, debido a la estrechez de la vivienda: "las camas es cierto se hallan juntas con solo la división de un tablado, pues no hay otra comodidad en dicha casa". Pero para al tribunal eclesiástico esas razones no le convencen y, no sin rigor malicioso, el fiscal le arguye al viejo cura que, a la vista de la disposición de las camas, que

no debe saber aquello del sr. San Agustín: estar siempre con una mujer y no conocer la mujer ¿no es por ventura, dice el Santo, mayor milagro que resucitar a un muerto? O es falso el dicho del Santo, que no puede ser, o hace milagros el cura confesante, o forzosamente vive el cura confesante mal divertido y amancebado con su criada. Elija una de las tres partes de la pregunta.

Con buen juicio, el anciano sacerdote respondió que "no tiene solución que dar al contenido de la pregunta", para acabar admitiendo que había tomado posesión del curato unos quince años atrás, sin recibir las órdenes, y de presbítero procuró instruirse, "y diciendo la verdad, como la confiesa, nunca logró instruirse en dicho rezo como correspondía y que es cierto que formalmente nunca supo rezar, y luego en sus años y falto de vista (...), todo se le escapó y olvidó" ${ }^{88}$.

El fiscal eclesiástico también apretó en 1765 a don Diego Carnero, mercenario Santa María de Proendos. A pesar de que varios clérigos que le conocían declararon que no daba nota ni escándalo con la criada y él intentó argumentar que era mujer de vida libre y que recibía a hombres en casa cuando él estaba ausente, sometido a un interrogatorio severo acaba confesando que vivía en concubinato continuado, eso sí, debido a las provocaciones de ella:

87 Ibidem, mazo 45. La forzada quedó embarazada y acabó presa en Monforte.

88 Ibidem, mazo 18. Se le condena a ejercicios espirituales en algún convento de Santiago. 
dijo que no puede negar las fuertes razones de los cargos y confiesa que (...) los tiempos que estaba en ella (casa) y en compañía de dicha moza vivía con ella regularmente incontinentemente, pues ya había el tocamiento feo, el ósculo, el enrriedo lascivo e ya el auto torpe a que regularmente la moza le provocaba muchas veces; cuando se ofrecía esto, no celebraba dicho presbítero hasta que pasasen algunos días, pero administraba el sacramento de la penitencia.

La conclusión es que "tantos sacrificios (misas) como hizo cuantos sacrilegios cometió", y que las absoluciones fueron inválidas ${ }^{89}$.

La desidia en la administración de los sacramentos y en la celebración de otras prácticas propias del cristianismo campesino también podía dar origen a conflictos. Así, los feligreses de San Lorenzo Fiz de Robra se quejaban en 1765 de que su rector no cumplía con las obligaciones propias de un pastor de almas, y encima cobraba excesivos derechos. Al parecer, varios vecinos murieran sin sacramentos y no tenían lugar en la parroquia rogativas ni conjuros a truenos y tempestades, pues impedía tocar la campana: "debiendo dicho cura conjurar los truenos y tempestades que aflixen y destruyen los campos sembrados de todo género y hacer las más rogativas al asunto correspondientes, executa lo contrario", llegando a proclamar en festivo, al ofertorio de la misa mayor, que ojalá que "Nuestro Señor Jesucristo permitiese se pudriese todo el fruto, y lo llevase el granizo, y que nunca grano cogiesen sus feligreses, que para él no le había de faltar", algo que indignó a los asistentes, pues semejante expresión "es de extrañar en cualquier christiano católico, mayormente un cura pastor de almas"

En la década de 1780, el cura de San Pedro de Canaval y anejo se dejaba arrastrar por una incontinencia que sorprendió y escandalizó a unos misioneros, que lo denunciaron en 1789 ante la curia diocesana, que ya le había condenado a ejercicios espirituales con antelación, pero que por lo sucedido después no le aprovecharon. Si las autoridades eclesiásticas no toman medidas duras, dicen en carta al prelado, arruinará la parroquia “y su estallido se podrá oír en el Reino y aun fuera de él”. El remedio ha de consistir en "recluir a este hombre algunos años o toda su vida en una clausura, a donde no pueda echar la garra a mujer alguna. Rara, o ninguna, de cualquier estado, sea de día o de noche, se libra de ellas. Es el racional más lujurioso que he encontrado y le pedía a la Divina Magestad me proporcionase remedio para poder batirle por el fuego externo" (sic). Al presente, añaden, hay dos mozas embarazadas de él y es preciso conseguir que se espontaneen ante la justicia ordinaria y después asistirlas, para librarlas del rigor de los padres: "Esto claman estas pobres ovejas, todas escandalizadas y las más devoradas por este lobo". La mala vida ya la arrastraba de otra parroquia, "y (en) la que ahora está la va alargando con más eslabones: en solo ella se le cuentan públicas seis proles, y algunas más en las inmediatas. Las ocultas, Deus scit, y con todo está al frente de un rebaño de Christo en calidad de pastor. Incomprensibles juicios de Dios" $"$.

La debilidad en materia de mujeres, según expresión de la época, no parece desde luego excepcional, y si quedaba limitada al trato con las criadas o con alguna

Ibidem, mazo 46. La criada embarazada fue expulsada de casa, y hay sospechas de que estará con sus padres.

90 Ibidem, mazo 12. El cura dice que el toque de campana "le rompe la cabeza". Varios feligreses que quejan además de que va a recoger los cadáveres vestido de modo indecente y no reza los responsos en los sitios de costumbre.

$91 \quad$ Ibidem, mazo 46. 
joven soltera no solía causar escándalo, salvo cuando daba pie a que los rectores se volviesen avariciosos en la cobranza de derechos, como decía en 1825 el arcipreste de Bezoucos del párroco de Cabanas: "no da limosna, que debe ser por causa de la criada, que es quien gobierna". En los informes que envían los arciprestes a la curia diocesana de Santiago en la década de 1820 los rumores originados por las relaciones entre curas y criadas son mencionados como algo a evitar, pero sin tratarlos como asuntos graves; solo en casos de conductas muy desarregladas los textos adquieren un tono censorio. Así, el arcipreste de Bergantiños manifiesta su indignación por la conducta del cura de Bertoa, don Simón Godoy y Castro:

Los muchos años que hace que es cura, que pasan de cuarenta, lexos de haber debilitado sus excesos parece que cada año que pasa sobre su cabeza aumenta su vigor para lo malo (...). En todos los hombres domina un vicio con preferencia a los demás, si la religión y la razón no los combaten, pero en él todos se aunaron, sin que pueda decirse en cuál exceda. Intemperancia, luxuria, abandono de los deberes del sacerdocio y ministerio parroquial, genio díscolo, pleiteante, inobediente, insolente, ignorante y escandaloso, es el epílogo de su vida.

Estuvo amancebado con una criada vizcaína, que casó con un sobrino, y que con posterioridad le pegaba al cura. Y "para complemento de la descripción de tan descarriada conducta solo me falta añadir que una cuadra de caballos, por descuidado que sea el criado, se halla con más aseo que el santuario de todo un Dios". Fue objeto de varias denuncias y correcciones y se trata de un caso excepcional en el arciprestazgo, pero el hecho de que un clérigo de vida tan desarreglada como este, o como el citado de San Pedro de Canaval, pudiese ejercer la cura de almas durante años tampoco deja de resultar ilustrativo ${ }^{92}$.

\section{Epílogo: de la adhesión a la política religiosa "ilustrada" a la militancia antiliberal}

A pesar de que las diversidades internas del clero rural aconsejan no generalizar en lo referido a su formación y comportamientos, hay indicios de que la política religiosa posterior al concordato de 1753 favoreció algunos cambios, en particular en los curas de almas y en los mercenarios que aspiraban a serlo. El concordato dejó en vigor los derechos de patronato particulares, lo que en Galicia suponía una limitación considerable, y de hecho la reforma beneficial, impulsada por real cédula de 14 de julio de 1769, apenas afectó a la red parroquial, salvo en la diócesis de Tui, en donde, a petición de los vecinos, se crearon 32 nuevas feligresías, que se añadieron a las 248 existentes a mediados del XVIII.

Resulta evidente que la política religiosa de la segunda mitad del XVIII está orientada en lo fundamental a reforzar la situación económica y canónica de los curas de almas y mejorar su formación intelectual (de ahí la real cédula de 14 de agosto de 1768 sobre la erección de seminarios conciliares), pues se esperaba de ellos que

92 Archivo Histórico Diocesano de Santiago, Fondo Xeral, leg. 1.186/1. En 1825 el sacerdote se hallaba impedido de las manos, llevaba varios años sin celebrar y se ayudaba de un patrimonista. 
fueran activos agentes del reformismo. En el mismo sentido, las medidas pretendían también fortalecer la centralidad del templo parroquial como lugar de culto frente a ermitas, santuarios y conventos, muy frecuentados por personas con una devoción indiscreta, externa, festiva y semiprofana, alejada del ideal de piedad interior de raíz más erasmiana que jansenista que defendían con poco éxito los ministros y obispos reformistas ${ }^{93}$. En este contexto, los curas y vicarios sabían que los vientos soplaban a su favor, que la dignidad de su ministerio era reconocida por el poder político y que, en definitiva, en medio de la fronda de seculares y regulares ellos eran los únicos que trabajaban.

El caso es que desde fines del XVIII se desató una verdadera cascada de pleitos entablados por párrocos y vicarios que reclamaban a los patronos mejor dotación, o porque recibían solo una congrua o porque las crisis agrarias reducían la masa decimal. Los obispos y sus provisores tendieron a apoyarles en los tribunales diocesanos y ante la Cámara y la Nunciatura. Podría citar muchos casos, a partir de la documentación de monasterios como Oseira, Sobrado y Melón, cuyos gastos se incrementaron para hacer frente con poco éxito a las demandas de sus vicarios. Los obispos de Mondoñedo, por ejemplo, no dudaron en redotar curatos de presentación de los monasterios de Monfero y Meira, del propio cabildo catedralicio y de varias casas nobles ${ }^{94}$.

Esta actitud reivindicativa de párrocos y vicarios, que Maximiliano Barrio Gozalo documentó en diversas diócesis españolas y que está influida por la propia legislación ${ }^{95}$, coincide al tiempo con nuevas exigencias de las comunidades parroquiales, que reclaman si es necesario la erección de nuevas parroquias para poder asistir con más facilidad a la iglesia, o, en último caso, la misa en días festivos en alguna capilla, lo que no siempre era bien visto por los obispos, que desconfiaban de los templos ajenos al parroquial. E iban más allá, al solicitar también que los diezmos tuviesen un destino acorde con su teórica finalidad originaria: una vez garantizado el sustento del cura, el resto debería distribuirse en limosnas y en obras comunitarias. Esto era lo que exigían los vecinos de numerosas parroquias de Mondoñedo, que desde 1772 venían sosteniendo con el cabildo, obispo, y varios curas un enconado pleito por el diezmo de las patatas: "si repasamos los oficios o escribanías no se tropieza a cada paso con otra cosa que fundaciones vinculares hechas por párrocos a favor de deudos y parientes, así como escrituras de donaciones y dotes (...) ¿Y para esto oprimen a sus feligreses hostigándoles con pleitos?"96.

La puesta en funcionamiento de los nuevos seminarios conciliares en Mondoñedo (1772), Lugo y Monforte (década de 1780) y Ourense (1804), con estudios de

93 Vid., sobre estos temas, Egido, T.: "Religión”, en Aguilar Piñal, F.(ed.): Historia literaria de España en el siglo XVIII, Madrid, Trotta, 1996, pp. 739-814; Hermann, C.: L'Église d'Espagne sous le Patronage Royal, 1474-1834: Essai d'ecclesiologie politique, Madrid, Casa de Vélazquez, 1988, y Barrio Gozalo, M.: El sistema beneficial de la iglesia española en el Antiguo Régimen (1475-1834), Universidad de Alicante, 2010.

94 La información procedente de los libros de pleitos de diversos monasterios en Saavedra, P.: La opulencia de los hijos de San Bernardo. El Císter en Galicia, c. 1480-1835, Prensas Universitarias de Zaragoza, 2021, pp. 355-375. Hay también información sobre la redotación de curatos en el Archivo Histórico Nacional, Patronato Real, legs. 15. 956, 15.960, 15996, 16.682 (obispado de Mondoñedo, con demandas de vicarios que afectan a los monasterios de Meira, Lourenzá, Monfero, al cabildo y a algunas casas nobles); legs. 15.926 y 15.958, con expedientes del obispado de Lugo.

95 Barrio Gozalo, M.: "Las condiciones materiales del clero parroquial del obispado de Segovia en el siglo XVIII. Normativa legal sobre ingresos o «congrua clerical»", Investigaciones Históricas, 11 (1991), pp. 9-34.

96 Fernández González, op. cit. (nota 12), p. 342. 
Filosofía y Teología, pronto incorporados a la Universidad, contribuyó sin duda a una mejor formación del clero parroquial, una parte del cual se muestra claramente comprometido con una política reformista, orientada a hacer de los rectores unos patriotas que debían contribuir al bienestar material de sus feligreses. El punto en donde más claramente se puso de manifiesto ese compromiso fue, sin duda, en la dotación de escuelas de escribir, leer y contar: hasta el 50 por cien de las muchas creadas en el obispado de Tui desde 1750 a 1850 lo fueron por iniciativa de abades parroquiales, que destinaron una parte de sus cuantiosos ingresos decimales a este fin. Pero los ejemplos podrían extenderse a buena parte de Galicia. Está claro que a los fundadores de escuelas les movía un afán de catequización, pero también de mejora de las condiciones de vida y de promoción social, pues como decía el rector de la parroquia de San Vicenzo de Lagoa en 1992, al destinar un fondo a la paga de un maestro a la vista de la difusión de la industria textil rural, sin la doctrina y las primeras letras "no pueden tenerse aquellos progresos que puede proporcionar a cada uno su fortuna, ni emprender ninguna carrera literata, girar comercios, ni ejercer otros empleos útiles a la república y bien común"97.

Por otra parte, si el concordato de 1753 respetó los derechos de patronato particulares, algunos obispos presionaron a los titulares para que aceptasen cubrir las vacantes por concurso o propusiesen candidatos idóneos. Y aunque fuesen pocas las parroquias que los prelados podían sacar a concurso, el número de participantes parece muy elevado, con lo que el impacto de esta práctica sobre el clero era muy superior al que de entrada podría pensarse. Así, en la minuciosa relación que en 1780 presenta el obispo de Ourense de las vacantes cubiertas por concurso podemos comprobar que para el de San Miguel de Lebosende (cuyo valor ascendía a 4.400 reales) hubo 33 opositores; para el de Santa María de Padornelo (7.000 reales), 20; para el de San Pedro de Ourelle (10.000 reales), 44; para el de San Miguel de Armeses (8.800 reales), 49; para el de San Lourenzo de Fustáns (8.000 reales); 40; para el de Santiago de Rubiás (8.000 reales), 47; para el de Santa María de Mandín (2.000 reales), 20; para el de Santo Estevo de Cambeo (5.000 reales), 46; para el de San Miguel de Ramil (3.300 reales), 27; e incluso para cubrir la vicaría de Santiago Gustei, que solo tiene una modesta congrua de 960, por cobrar el cabildo los diezmos, se presentaron 12 candidatos $^{98}$. Una parte de los opositores está formada por curas de almas que desean ascender y el resto por vicarios y mercenarios que aspiran a una rectoría permanente. Es significativo también que en la documentación de Gracia y Justicia de Simancas figuren currículos impresos de sacerdotes que participan en concursos, sea a curatos o a canonjías ${ }^{99}$.

La política religiosa posterior al concordato de 1753 sin duda creó una relación virtuosa entre una parte del clero parroquial y los ministros que impulsaron la reforma beneficial. Pero todo cambió a raíz de las Cortes de Cádiz, y sobre todo del Trienio Liberal, cuando el diezmo fue reducido a la mitad. De la militancia antiliberal de la inmensa mayoría de los sacerdotes de Galicia caben pocas dudas, toda vez

97 Archivo Histórico Diocesano de Mondoñedo, leg. correspondiente a Obras pías, con referencia a otras fundaciones. Sobre la dotación de escuelas por los abades tudenses, Obelleiro Piñón, L.: As escolas de fundación en Galiza: unha necesidade social de alfabetización: o caso de provincia de Pontevedra, Vigo, A Nosa Terra, 2007; la evolución de la red escolar en Sanz, M.: "Alfabetización y escolarización en Galicia a finales del Antiguo Régimen”, Obradoiro de Historia Moderna, 1 (1992), pp. 229-249.

98 AGS, Gracia y Justicia, leg. 321.

99 Por ejemplo, en los legs. 325 y 459. 
que en los informes que los arciprestes envían a los prelados los "afectos al sistema" son excepciones. Ilustrativos son al respecto los correspondientes a la diócesis de Compostela, de 1825: los arciprestes afirman que la inmensa mayoría de curas y mercenarios trabajaron en obsequio de la religión y del monarca, siéndoles odiosa la revolución, salvo a tal cual "loco, exaltado e inmoral", aunque alguno de estos pronto se convenció de su error, como el rector de Soñeiro, "afecto al sistema (y) su panegírico mientras no se tocó a los diezmos de los curas"100.

Durante la revolución liberal tuvo lugar por tanto un acusado proceso de homogeneización ideológica y cultural del clero parroquial, favorecido por la reacción ante las medidas que golpearon con dureza su situación económica, en especial la abolición del diezmo y también la desamortización, y por la información impartida en los seminarios y las directrices de los prelados, varios de ellos simpatizantes del carlismo. Este proceso se vio reforzado por otro de tipo social, una vez que las élites tienden a desertar de la carrera clerical, que ofrece pocas expectativas económicas y de estatus, y que queda copada por los hijos de campesinos y de familias urbanas modestas. En esta coyuntura, como ha señalado el profesor Xosé Ramón Barreiro, el clero parroquial se convierte en una "clase" con identidad propia, basada en una formación escolástica alejada de las transformaciones de todo tipo que estaba notando el mundo contemporáneo y que no debían ser entendidas, sino combatidas ${ }^{101}$.

\section{Bibliografía}

Barreiro Fernández, X. R.: A Galicia do Antigo Réxime. O Ensino, a Ilustración e a Política, A Coruña, Hércules de ediciones, 1991.

Barreiro Fernández, X. R. (coord.): Historia da Universidade de Santiago de Compostela, Santiago de Compostela, Universidade de Santiago de Compostela, 1998, vol. I.

Barreiro Fernández, X. R: "Edad Contemporánea: los hombres de altar (Aproximación al clero como grupo social”, Sémata, 7/8 (1996), p. 187.

Barreiro Fernández, X. R.: “A reforma parroquial de 1867: a diócese de Santiago de Compostela”, en García Pazos, F. (coord.): A parroquia en Galicia. Pasado, presente e futuro, Santiago de Compostela, Xunta de Galicia, 2009, pp. 126-127.

Barreiro Mallón, B.: La jurisdicción de Xallas en el siglo XVIII. Población, sociedad y economía, Santiago de Compostela, Universidad de Santiago de Compostela, 1973.

Barreiro Mallón, B.: "El clero de la diócesis de Santiago: estructura y comportamientos, siglos XVI-XIX”, Compostellanum, XXXIII (1988), pp. 469-508.

Barreiro Mallón, B.: "El clero de la diócesis de Santiago a través de las visitas pastorales, visitas ad limina, registros de licencias ministeriales y concursos de curatos", Compostellanum, XXXV (1990), pp. 489-515.

Barreiro Mallón, B.: "La diócesis de Mondoñedo en la Edad Moderna", en Historia de las diócesis españolas. 15. Iglesias de Lugo, Mondoñedo-Ferrol y Orense, Madrid, BAC, 2002, pp. 255-334.

\footnotetext{
100 Archivo Histórico Diocesano de Santiago, Fondo General, leg. 1.186, con amplia información sobre el comportamiento de los clérigos durante el Trienio. Sobre los pocos clérigos liberales, Vázquez Vilanova, J. A.: "El clero liberal de la diócesis compostelana durante le primera mitad del siglo XIX: análisis e interpretación de un fenómeno peculiar", Cuadernos de Estudios Gallegos, 48 (2001), pp. 161-180.

101 Barreiro Fernández, op. cit. (nota 57), pp. 187-204 ("Como se constituye una clase”).
} 
Barreiro Mallón, B.: "La diócesis de Santiago en la época moderna", Historia de las diócesis españolas. 14. Iglesias de Santiago de Compostela y Tuy-Vigo, Madrid, 2002, pp. 177408.

Barreiro Mallón, B.: "Estudiantes y curas en la diócesis de Santiago en el siglo XVIII", en Estudios en homenaje al profesor Teófanes Egido, Valladolid, Junta de Castilla y León, 2004, vol. 1, pp. 103-130.

Barrio Gozalo, M.: El sistema beneficial de la iglesia española en el Antiguo Régimen (14751834), Universidad de Alicante, 2010.

Barrio Gozalo, M.: "Las condiciones materiales del clero parroquial del obispado de Segovia en el siglo XVIII. Normativa legal sobre ingresos o «congrua clerical»", Investigaciones Históricas, 11 (1991), pp. 9-34.

Barrio Gozalo, M.: "Muchos clérigos y pocos curas. El acceso a la clerecía y a los beneficios menores en la España Moderna”, Cuadernos de Investigación Histórica, 25 (2008), pp. 293-332

Barrio Gozalo, M.: El clero en la España moderna, Córdoba, Cajasur, 2010.

Barrio Gozalo, M.: "El clero en la España del siglo XVIII. Balance historiográfico y perspectivas", Cuadernos de Estudios del Siglo XVIII, 22 (2017), pp. 51-79.

Brumont, F.: "La clergé diocésain dans la France Moderne", Obradoiro de Historia Moderna, 22 (2013), pp. 231-248.

Candau Chacón, M. L.: La carrera eclesiástica en el siglo XVIII: modelos, cauces y formas de promoción en la Sevilla rural, Sevilla, Universidad de Sevilla, 1993.

Candau Chacón, M. ${ }^{a}$ L.: Los delitos y las penas en el mundo eclesiástico sevillano del siglo XVIII, Sevilla, Diputación Provincial, 1993.

Candau Chacón, M. L.: El clero rural de Sevilla en el siglo XVIII, Sevilla, Caja Rural de Sevilla, 1994.

Candau Chacón, M. L.: "El clero secular y la historiografía. Tendencias, fuentes y estudios referidos a la modernidad", Revista de Historiografía, 2 (2005), pp. 75-89.

Contreras, J.: El Santo Oficio de la Inquisición en Galicia (poder, sociedad y cultura), Madrid, Akal, 1982.

Corral Martínez, A.: Historia y pedagogía del seminario de Astorga, 1766-1966, Ponferrada, Peñalba Impresión, 1993.

Cortés Peña, A. L. y López Guadalupe Muñoz, M. L. (eds.): La Iglesia española en la Edad Moderna: balance y perspectivas, Madrid, Abada, 2007.

Domínguez García, J. M.: Cátedras de gramática y educación en Galicia, siglos XVI-XVII, A Coruña, Fundación Pedro Barrié de la Maza, 2010.

Dubert, I.: Historia de la familia en Galicia en la Edad Moderna, 1550-1850, Sada (A Coruña), Ediciós do Castro, 1992.

Dubert, I.: Cultura popular e imaxinario social en Galicia, 1480-1900, Universidade de Santiago de Compostela, 2007.

Dubert, I.: "Alma de curas y curas de almas. Moral y comportamientos en eclesiásticos en la Galicia interior durante el Antiguo Régimen”, Sémata, 7/8 (1996), pp. 379-412.

Dubert, I.: "El clero rural en Galicia a fines del Antiguo Régimen”, en Romaní Martínez, M. y Novoa Gómez, M. A.: Homenaje a José García Oro, Santiago de Compostela, Universidade de Santiago de Compostela, 2002, pp. 101-118.

Dubert, I.: "Montagnes, clercs et vocations religieuses dans la Galice intérieure, 1685-1859", en Brunet, S. y Lemaitre, N.: Clergés, communautés et famille des montagnes d'Europe, Paris, Éditions de la Sorbonne, 2005, pp. 75-89.

Dubert, I. y Fernández Cortizo, C.: "Entre el «regocijo» y la «bienaventuranza». Iglesia y sociabilidad campesina en la Galicia del Antiguo Régimen”, Sémata, 6 (1994), pp. 237-262. 
Egido, T.: "Religión", en Aguilar Piñal, F.(ed.): Historia literaria de España en el siglo XVIII, Madrid, Trotta, 1996, pp. 739-814.

Fariña Jamardo, X.: A parroquia rural en Galicia, Santiago de Compostela, EGAP, 1996.

Fernández Cortizo, C.: La tierra de Montes en el siglo XVIII: estructura demográfica y sistema familiar en una sociedad rural, Tesis doctoral inédita, Facultade de Xeografía e Historia, Universidade de Santiago de Compostela, 2001.

Fernández Cortizo, C.: "Les missions populaires dans le Royaume de Galice", en Missions religieuses modernes. Notre lieu est le monde, Rome, École Française de Rome, 2007, pp. 315-340.

Fernández González, A. F.: A fiscalidade eclesiástica en Galicia, 1750-1850, Tese doutoral inédita, Universidade de Santiago de Compostela, Facultade de Ciencias Económicas e Empresariais, 1995.

Fernández González, A. I.: "Los grupos de poder local en Galicia, 1750-1850, Noticiario de Historia Agraria, 9 (1995), pp. 129-153.

Ferrer i Alos, L.: "Acceso y distribución de los medios de producción. Herencia y reproducción social”, en Chacón, F. y Bestard, J. (dirs.): Familias: historia de la sociedad española (del final de la Edad Media a nuestros días), Madrid, Cátedra, 2011, pp. 255-324.

Fraga Vázquez, G.: El seminario diocesano de Lugo, Lugo, Diputación Provincial, 1989.

García Oro, J.: "La vida religiosa en el Valle de Or a principios del siglo XVI"; Compostellanum, 24 (1979), pp. 121-172.

García Pazos, F. (coord.): A parroquia en Galicia. Pasado, presente e futuro, Santiago de Compostela, Xunta de Galicia, 2009.

Garrote Martín, A.: El derecho de patronato en la presentación a beneficios eclesiásticos según las leyes canónicas y el derecho particular de España, Lugo, La Voz de la Verdad, 1921.

González Lopo, D.: Los comportamientos religiosos en la Galicia del Barroco, Santiago de Compostela, Xunta de Galicia, 2002.

González Lopo, D.: "De bárbaros a devotos: la reforma tridentina en Galicia (1550-1750)", en Religión, herejías y revueltas sociales en Europa y América, Bilbao, Universidad del País Vasco, 2008, pp. 141-174.

González Reboredo, X. M.: Os santos titulares de parroquias en Galiza, Santiago de Compostela, Sotelo Blanco, 2012.

Goody, J.: La domesticación del pensamiento salvaje, Madrid, Akal, 1985.

Goody, J. (ed.): Cultura escrita en sociedades tradicionales, Barcelona, Gedisa, 1996.

Hermann, C.: L'Église d'Espagne sous le Patronage Royal, 1474-1834: Essai d'ecclesiologie politique, Madrid, Casa de Vélazquez, 1988.

Hermann, C.: "Iglesia y poder: el encuadramiento pastoral en el siglo XVIII", Cuadernos de Investigación Histórica, 6 (1982), pp. 137-150.

Herr, R.: Memorias del cura liberal don Juan Antonio Posse, con su Discurso sobre la Constitución de 1812, Madrid, Siglo XXI, 1984.

Irigoyen López, A.: "Los tratados de perfección sacerdotal y la construcción de la identidad social del clero en la España del siglo XVII", Hispania, 68, 230 (2008), pp. 707-734.

Le Bras, G.: L'Église et le village, Paris, Flammarion, 1976.

Lisón Tolosana, C.: Antropología cultural de Galicia, Madrid, Siglo XXI, 1971.

López Díaz, A. y otros (eds.): O Seminario de Mondoñedo, 1565-2013, Centro de formación e de promoción cultural, Lugo, Deputación Provincial, 2015.

López Morán, B.: El bandolerismo gallego en la primera mitad del siglo XIX, Sada (A Coruña), Ediciós do Castro, 1995. 
López, Roberto J.: "Las cofradías gallegas en el Antiguo Régimen”, en Obradoiro de Historia Moderna. Homenaje al profesor Antonio Eiras Roel en el XXV aniversario de su cátedra, Santiago de Compostela, Universidad de Santiago, 1990, pp. 181-200.

Marquès, J. M.: "La Iglesia de Gerona", en Historia de las diócesis españolas. 2 Barcelona, Terrrassa, San Feliu de Llobregat, Gerona, Madrid, BAC, 2006, pp. 463-683.

Maure Rivas, X.: "Estudio de Gramática de Tui: testemuño dunha represión lingüística", $A$ Trabe de Ouro, 27 (1996), pp. 99-109.

Morgado García, A.: El clero gaditano a fines del Antiguo Régimen: estudio de las órdenes sacerdotales, 1700-1834, Cádiz, Fundación Municipal de Cultura, 1989.

Morgado García, A.: Ser clérigo en la España del Antiguo Régimen, Cádiz, Universidad de Cádiz, 2000,

Morgado García, A.: La diócesis de Cádiz de Trento a la desamortización, Cádiz, Universidad de Cádiz, 2008.

Morgado, A: “Curas y parroquias en la diócesis de Cádiz (1714-1834)”, Obradoiro de Historia Moderna, 22 (2013), pp. 207-230.

Nubiola, C. y Turchini, A. (a cura di): Visite pastorale ed elaborazione dei dati: esperienze e metodi, Bologna, Il Mulino, 1993.

Obelleiro Piñón, L.: As escolas de fundación en Galiza: unha necesidade social de alfabetización: o caso de provincia de Pontevedra, Vigo, A Nosa Terra, 2007.

Pérez García, J. M.: Un modelo de sociedad rural de Antiguo Régimen en la Galicia costera, Santiago de Compostela, Universidad de Santiago de Compostela, 1979.

Pérez López, S.: "Las visitas pastorales como fuente histórica. Aportación a su estudio en la diócesis de Mondoñedo", Estudios Mindonienses, 3 (1987), pp. 133-165.

Pérez López, S. y Cantelar Rodríguez, F. (eds.): Sínodos mindonienses dos séculos XVI e XVII, Santiago de Compostela, Xunta de Galicia, 2001.

Presedo Garazo, A.: "O clero secular galego de orixe fidalgo na Época Moderna: unha poderosa elite local", Compostellanum, LII (2007), pp. 651-669.

Presedo Garazo, A.: “"Sacerdotes que por estar en casa de sus parientes no tienen yndividuos familiares»: hogares de eclesiásticos y hogares con eclesiásticos en la diócesis de Lugo a mediados del siglo XVIII", López Díaz, M. (ed.): Historia y Modernidad. Homenaje al profesor José M. Pérez García, Vigo, Universidade de Vigo, 2009, vol. 2, pp. 207-224.

Puigvert, J. (ed.): Les visites pastorals. Del orígens medievals a l'època contemporània, Girona, CCG EDICIONS, 2003.

Rey Castelao, O.: A Galicia clásica e barroca, Vigo, Galaxia, 1998.

Rey Castelao, O.: "El reparto social del diezmo en Galicia", Obradoiro de Historia Moderna, 1 (1992), pp. 145-162.

Rey Castelao, O.: “Edad Moderna: Iglesia y religión”, Sémata, 7/8 (1996), pp. 141-180.

Rey Castelao, O.: “¿Biografía o hagiografía? Memorias Breves del arzobispo Don Francisco Blanco de Salcedo", en Barreiro Mallón, B. y otros (coords.): Cuatro textos. Cuatro contextos. Ensayos de Historia Cultural de Galicia, Santiago de Compostela, Maxin S.L., 2004, pp. 13-63.

Rivera Vázquez, E.: Galicia y los jesuitas. Sus colegios y enseñanzas en los siglos XVI al XVIII, A Coruña, Fundación Pedro Barrié de la Maza, 1989.

Rodríguez Ferreiro, H.: A xurisdicción do Morrazo, ss. XVII-XVIII, Pontevedra, Deputación Provincial, 2004.

Rubio Pérez, L.: "Curas, feligreses y concejos: relaciones, conflictos y consensos en el reino de León durante la edad moderna", Tiempos Modernos, 36 (2018). 
Saavedra, P.: Economía, política y sociedad en Galicia. La provincia de Mondoñedo, 14801830, Madrid, Xunta de Galicia, 1985.

Saavedra, P.: La vida cotidiana en la Galicia del Antiguo Régimen, Barcelona, Crítica, 1994.

Saavedra, P.: Demarcacións, topónimos, papeis, memoria. Sobre a división e control do territorio na Galicia moderna, A Coruña, Real Academia Galega, 2013.

Saavedra, P.: La opulencia de los hijos de San Bernardo. El Císter en Galicia, c. 1480-1835, Prensas Universitarias de Zaragoza, 2021.

Saavedra, P.: "El clero rural en la España Moderna", en García González, F., Béaur, G. y Boudjaaba, F. (eds.): La historia rural en España y Francia (siglos XVI-XIX). Contribuciones para una historia comparada y renovada, Zaragoza, Prensas Universitarias de Zaragoza, 2016, pp. 339-383.

Saavedra, P.: "Los campesinos y sus curas", en Pérez Álvarez, M. J. y Rubio Pérez, L.: Campo y campesinos en la España Moderna, Madrid, FEHM/CSIC, 2012, pp. 19-86.

Saavedra, P., Sobrado Correa, H. y Presedo, A.: "La red parroquial y el clero rural en la Galicia de los siglos XVI-XIX: resultados de una investigación en curso"; Obradoiro de Historia Moderna, 22 (2013), pp. 93-128.

Sangalli, M. (ed.): Pastori, pope, prete, rabbini. La formazione del ministro di culto in Europe (secoli XVI-XIX), Roma, Carocci editore, 2005.

Sangalli, M.: "La formación del clero católico en la edad moderna. De Roma a Italia, a Europa", Manuscrits, 25 (2005), pp. 101-128.

Sanz, M.: “Alfabetización y escolarización en Galicia a finales del Antiguo Régimen”, Obradoiro de Historia Moderna, 1 (1992), pp. 229-249.

Sarmiento, fray M.: Catálogo de voces y frases de la lengua gallega, edición y estudio de José Luis Pensado, Universidad de Salamanca, 1973.

Sarmiento, fray M.: La educación de la juventud, edición de José Luis Pensado, Santiago de Compostela, Xunta de Galicia, 1984.

Sobrado Correa, H.: Las tierras de Lugo en la Edad Moderna, Economía campesina, familia y herencia, 1550-1860, A Coruña, Fundación Pedro Barrié de la Maza, 2001.

Sobrado Correa, H.: "Mediadores entre lo humano y lo divino. El clero parroquial como intermediario socio-económico y cultural en la Galicia del Antiguo Régimen”, en López Díaz, M. (ed.): Historia y Modernidad. Estudios en homenaje al profesor José M. Pérez García, Vigo, Universidade de Vigo, 2010, vol. II, pp. 317-336.

Torres de Villaroel, D.: Vida, edición de Dámaso Chicharro, Madrid, Cátedra, 1998.

Turchini, A.: "La nascita del sacerdocio como profesione", en Prodi, P. (ed.): Disciplina dell'anima, disciplina del corpo, disciplina della società tra medievo ed età moderna, Bolonia, Il Mulino, 1994, pp. 225-256.

Vázquez Vilanova, J. A.: "El clero liberal de la diócesis compostelana durante le primera mitad del siglo XIX: análisis e interpretación de un fenómeno peculiar", Cuadernos de Estudios Gallegos, 48 (2001), pp. 161-180. 